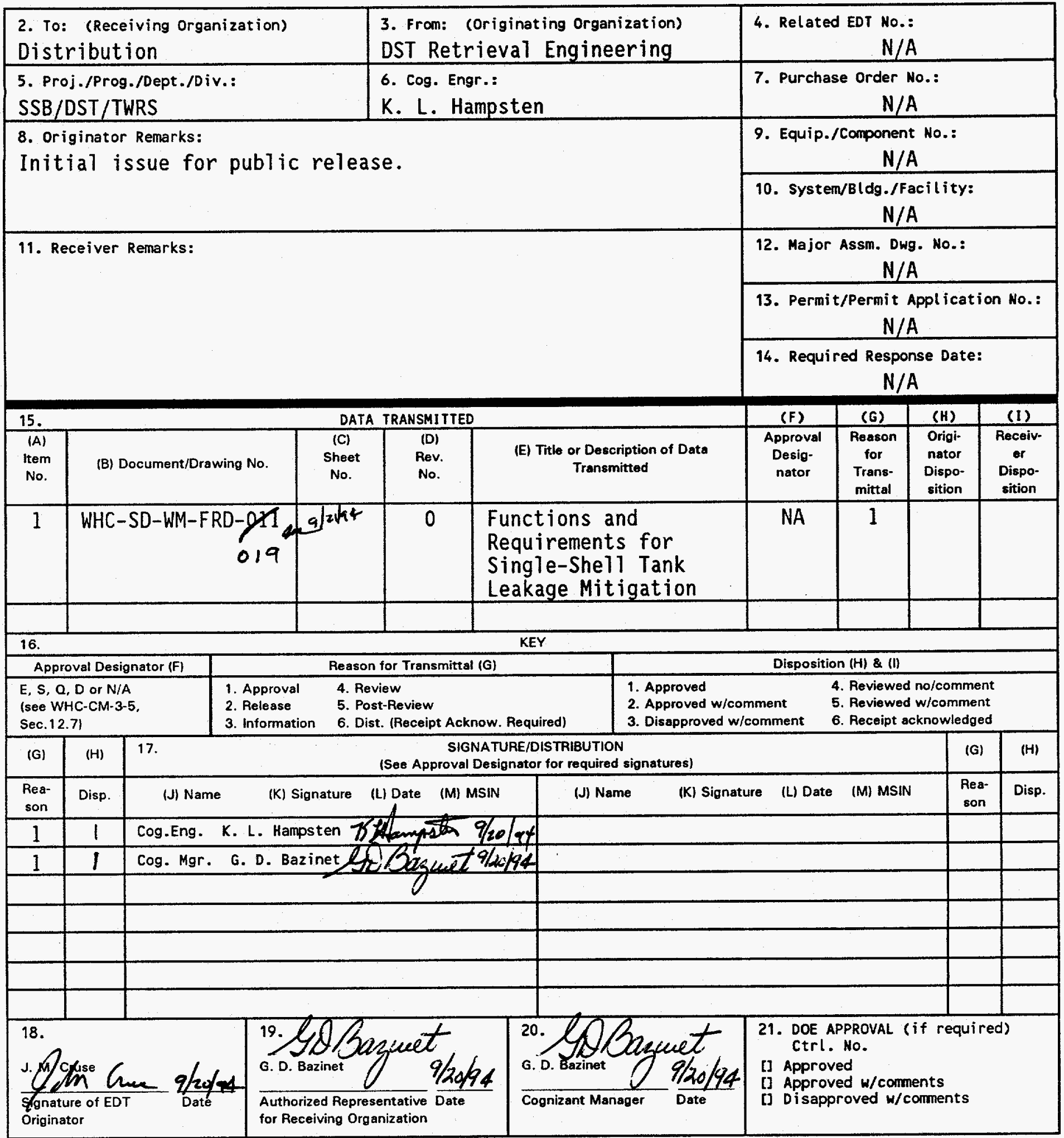




\section{DISCLAIMER}

This report was prepared as an account of work sponsored by an agency of the United States Government. Neither the United States Government nor any agency thereof, nor any of their employees, make any warranty, express or implied, or assumes any legal liability or responsibility for the accuracy, completeness, or usefulness of any information, apparatus, product, or process disclosed, or represents that its use would not infringe privately owned rights. Reference herein to any specific commercial product, process, or service by trade name, trademark, manufacturer, or otherwise does not necessarily constitute or imply its endorsement, recommendation, or favoring by the United States Government or any agency thereof. The views and opinions of authors expressed herein do not necessarily state or reflect those of the United States Government or any agency thereof. 


\section{DISCLAIMER}

Portions of this document may be illegible in electronic image products. Images are produced from the best available original document. 


\section{RELEASE AUTHORIZATION}

Document Number: $\quad$ WHC-SD-WM-FRD-019, Revision 0

Document Title: $\quad$ Functions and Requirements for Single-Shel1 Tank Leakage Mitigation

Release Date:

September 21, 1994

This document was reviewed following the procedures described in WHC-CM-3-4 and is:

APPROVED FOR PUBLIC RELEASE

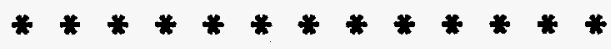

WHC Information Release Administration Specialist:

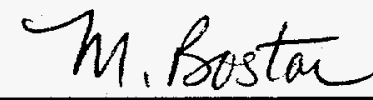

M. N. Boston

(Signature)

$\frac{9 / 21 / 94}{\text { (Date) }}$


2. Title

Functions and Requirements for Single-Shell Tank Leakage Mitigation

\section{Key Words}

Injected materials, frozen soil and desiccant barriers, functions and requirements, performance criteria.

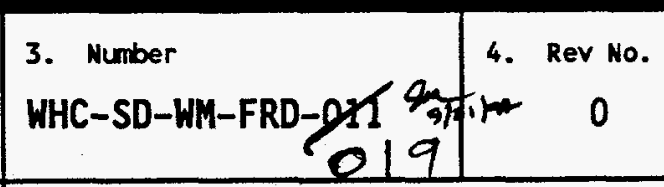

6. Author

Name: J. M. Cruse

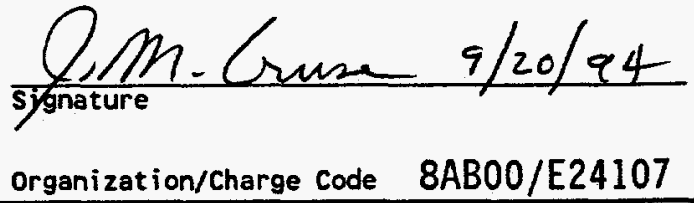

\section{Abstract}

This document provides the initial functions and requirements for the leakage mitigation mission applicable to past and potential future leakage from the Hanford Site's 149 single-shell high-level waste tanks. This mission is a part of the overall mission of the Westinghouse Hanford Company Tank Waste Remediation System division to remediate the tank waste in a safe and acceptable manner. Systems engineering principles are being applied to this effort.

A Mission Analysis has been completed, this document reflects the next step in the systems engineering approach to decompose the mission into primary functions and requirements. The functions and requirements in this document apply to mitigative actions to be taken regarding below ground leaks from SST containment boundaries and the resulting soil contamination. Leakage mitigation is invoked in the TWRS Program in three fourth level functions: (1) Store Waste, (2) Retrieve Waste, and (3) Disposition Excess Facilities (as identified in DOE/RL-92-60 Rev. 1, Tank Waste Remediation System Functions and Requirements).

8. PURPoSE AND USE OF DOCUMENT/This document was prepaped for yse wikh in the O.s. Department of Energe and ito contractors. It is to * be used only to perform, drect, or integrate work under U.S beparthent of Energy coptracts. This dogument is pot approred fof publit release until peviewed,

PATENT STATOS - This document copy since it is transmitted in advance of patent clearance, is mode available in confidence solely for use in performance of work ynder coptracts yith the 4 S. Depaytment of Energy. Inis docupent is not to be pubtished nor its coptents otherwise dioseminated or useg for purposes other than. specified abore before patent approval for such celease op use has been secuped, upon pequest, from the prtent coupsel, U.S. Depaptment of Energy Fieldoffice, Rithland, yta.

DIselaimeg - This yepory/was pfepared as an account of/work sponsored by on agency of the ynited states Gorernment. Neither the United stotes Government nop any gaency thereof hor any of thelr employes, not any of tbeir contractons, subgantractors or their employees makeo any yarranty/ expreas or julpl ied or assynes any logal liabilizy or responsiblity for the atcuracy, comploleness or any third party's ase or the resurts of such use of any information. appratys, product, or process disclged, or /epresepts thay tts use. hould not infringe privatel/ owned rights Reference hepe in to any spetific Comerciat prgatuct, preess, or seryce by trade name, trademark, manufactuper, op othephise, foes pot necessarity const tute of imply its endorsement, reconiendatjon, or fevoring by the Unifed stgtes Goyernment or an agenty thepeof for its contrgetors od subcontractory. The fiews and opinions of authbrs expessed berein do not nokessarily state or reflect those bf the unted states Government/or any/agency thereof/

9. Impact Level NA
10.

RELEASE STAMP

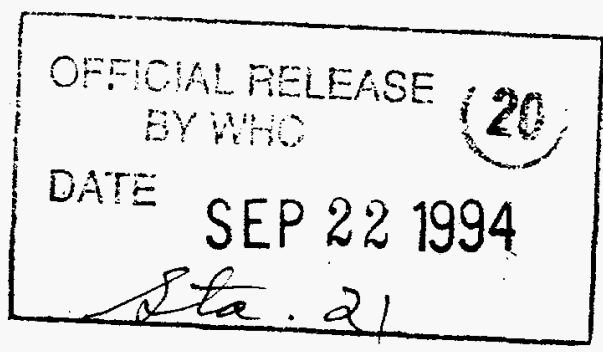

*APPROVED FOR PUBLIC RELEASE $m$. Bostan $9 / 21 / 94$
Information Release Administration 


\title{
Functions and Requirements for Single-Shell Tank Leakage Mitigation
}

\author{
J. M. Cruse
}

Date Published

September 1994

Prepared for the U.S. Department of Energy Office of Environmental Restoration and Waste Management

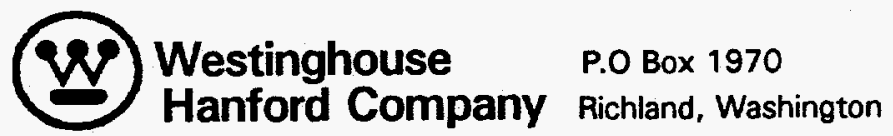

Hanford Operations and Engineering Contractor for the

U.S. Department of Energy under Contract DE-AC06-87RL10930 
WHC-SD-WM-FRD-019 REV. 0

This page intentionally left blank. 


\section{CONTENTS}

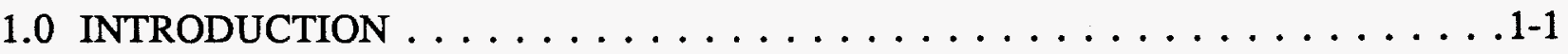

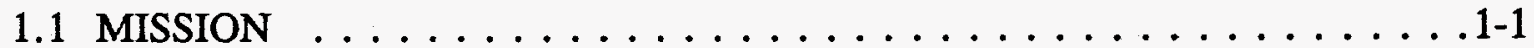

1.2 SCOPE . . . . . . . . . . . . . . . . . .

1.3 BACKGROUND INFORMATION $\ldots \ldots \ldots \ldots \ldots \ldots \ldots \ldots \ldots \ldots \ldots$

1.3.1 Single-Shell Tank Physical Description . . . . . . . . 1-3

1.3.2 Single-Shell Tank Waste Description . . . . . . . . . . 1-3

1.3.3 Hanford Site Geology . . . . . . . . . . . . . . 1-4

1.4 SYSTEMS ENGINEERING APPROACH $\ldots \ldots \ldots \ldots \ldots \ldots \ldots$

1.5 FUNCTIONS AND REQUIREMENTS DOCUMENT $\ldots \ldots \ldots \ldots \ldots$

2.0 FUNCTIONS AND REQUIREMENTS $\ldots \ldots \ldots \ldots \ldots \ldots \ldots \ldots \ldots \ldots \ldots \ldots . \ldots \ldots$

2.1 FUNCTION HIERARCHY $\ldots \ldots \ldots \ldots \ldots \ldots \ldots \ldots \ldots . . \ldots \ldots . . \ldots \ldots$

2.2 FUNCTION DESCRIPTION SHEETS $\ldots \ldots \ldots \ldots \ldots \ldots \ldots \ldots . . \ldots \ldots$

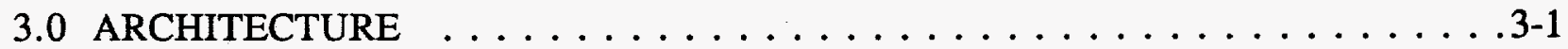

3.1 ARCHITECTURE HIERARCHY . . . . . . . . . . . . 3-1

3.2 ARCHITECTURE DESCRIPTION SHEETS $\ldots \ldots \ldots \ldots \ldots$. . . . . . .

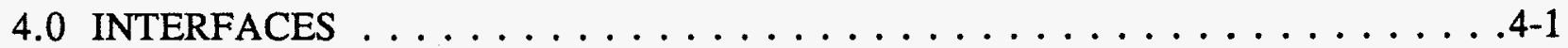

5.0 ITEMS NEEDING FURTHER RESOLUTION $\ldots \ldots \ldots \ldots \ldots \ldots \ldots$. $\ldots \ldots$

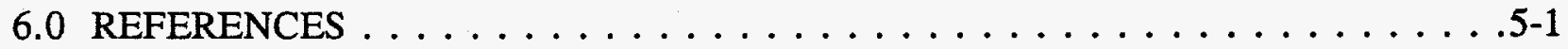

APPENDICES

A TWRS SYSTEMS ENGINEERING APPROACH $\ldots \ldots \ldots \ldots \ldots \ldots$ A-1

B GENERAL REQUIREMENTS APPLICABLE TO TANK FARMS . . . . . . . B B-1 


\section{LIST OF FIGURES}

2-1 SST Leakage Mitigation Function Hierarchy . . . . . . . . . . . . . . . . 2-2

2-2 Close-Coupled Subsurface Barrier Concept . . . . . . . . . . . . . . . . . . . . 2 2-49

2-3 Stand-Off (Vee) Subsurface Barrier Concept . . . . . . . . . . . . . . . . . 2-50

2-4 Stand-Off (Box) Subsurface Barrier Concept . . . . . . . . . . . . . . . . 2-51

3-1 SST Leakage Mitigation Architecture Hierarchy . . . . . . . . . . . . . . 3-2

\section{LIST OF TABLES}

2-1 SST Leakage Mitigation Requirements Allocation. . . . . . . . . . . 2-3 


\subsection{INTRODUCTION}

This document defines the functions and requirements for single-shell tank (SST) leakage mitigation, by application of the Systems Engineering process. A function is a definition of what a system or subsystem must accomplish to meet the overall mission; a requirement is a qualitative or quantitative statement of how well a function must be performed. Within the Tank Waste Remediation System (TWRS), requirements may be one of two types:

constraints and performance requirements. Constraints are imposed upon the function by the external environment (e.g., U.S. Congress, U.S. Environmental Protection Agency (EPA), Washington State Department of Ecology (Ecology), U.S. Department of Energy (DOE) Orders). Performance requirements are imposed upon the function by the TWRS Program itself and therefore may be traded with respect to other performance requirements to optimize overall performance. The document also identifies the interfaces between functions, and between the program and the external environment.

The functions and requirements will serve as a basis for the program technical baseline, as directed by DOE, Richland Operations Office (RL) (reference DOE-RL Letter 94-PRJ-018, R. W. Brown, RL, to President, Westinghouse Hanford Company (WHC), "Tank Waste Remediation System (TWRS) Project Documentation Methodology," dated March 17, 1994).

\subsection{MISSION}

The mission of the TWRS Program is "to store, treat, and immobilize highly radioactive Hanford waste in an environmentally sound, safe, and cost-effective manner" (RL 1993a). The scope of the TWRS Program includes project and program activities for receiving, storing, maintaining, treating, and disposing onsite, or packaging for offsite disposal, all Hanford tank waste. Hanford tank waste includes the contents of 149 SSTs and 28 double-shell tanks (DST), plus any new waste added to these facilities, and all encapsulated cesium and strontium stored onsite and returned from offsite users. A key element of the TWRS Program is retrieval of the waste in the SSTs. The waste stored in these underground tanks must be removed in order to minimize environmental, safety, and health risks associated with continuing waste storage.

Hydraulic sluicing is the primary approach currently envisioned for retrieval of the SST waste. The sluicing operations will typically add some level of working liquid to the tank to mobilize the solidified saltcakes and sludges. The design life of the tanks has expired and the integrity of the tank containment boundaries is in question. Historically, tank wastes have been released to the ground from leaks from SSTs and associated transfer lines, and other miscellaneous spills. Sixty-seven SSTs are assumed to have leaked a total volume of approximately 2,271 to $3,407 \mathrm{~m}^{3}$ (600,000 to $900,000 \mathrm{gal}$ ) (Hanlon 1993). Several studies 
(Lowe 1993, Schmittroth 1993) have indicated that the contaminants present in this volume of leakage could cause violation of groundwater quality standards, once the contaminants migrate through the vadose zone to the groundwater.

The Hanford SST tank farms were constructed during the period from 1943 to 1964. Retrieval of waste from the SSTs currently is scheduled for a 15-year processing campaign beginning in 2003 and ending in 2018, except tank C-106, which is planned for retrieval in 1997 to provide a demonstration of retrieval technology. Accordingly, the SSTs will be as old as 60 to 75 years at the initiation of retrieval, depending on the sequence for individual tanks.

The concerns of environmental impact because of migration of the contaminants that have already leaked from the tanks and the potential for additional leakage during retrieval have driven the initiative to evaluate alternatives for leakage mitigation. The TWRS program is investigating a number of options to mitigate past and potential future leakage from the SSTs. A mission analysis was conducted as documented in Mission Analysis Report for Single-Shell Tank Leakage Mitigation (WHC-SD-WM-MAR-001) and established the following mission statement:

Confine past and any future tank leaks, and remove resultant soil contamination to a level allowing closure of the single-shell tank farms in a safe and cost-effective manner.

This document reflects the next step in the systems engineering approach to decompose the mission into primary functions and requirements.

\subsection{SCOPE}

The functions and requirements in this document apply to mitigative actions to be taken regarding belowground leaks from SST containment boundaries and the resulting soil contamination. Leakage mitigation is invoked in the TWRS Program in three fourth-level functions: (1) Store Waste, (2) Retrieve Waste, and (3) Disposition Excess Facilities (as identified in DOE/RL-92-60 Rev. 1, Tank Waste Remediation System Functions and Requirements).

\subsection{BACKGROUND INFORMATION}

The official inventory for the waste stored in underground tanks on the Hanford Site is provided in Tank Farm Surveillance and Waste Status Summary Report for May 1993, WHCEP-0182-62 (WHC 1993a). This report is issued monthly and provides data on each of the underground waste storage tanks, and supplemental information regarding tank surveillance anomalies and ongoing investigations. 
The geology of the Hanford Site is complex. Significant variations exist both locally and across the site as a whole. The most current description and interpretation of the Hanford Site geology is provided in Delaney et al. (1991), Lindsey et al. (1992a), Lindsey et al. (1992b), and Reidel et al. (1992).

\subsubsection{Single-Shell Tank Physical Description}

There are 149 SSTs and 28 DSTs on the Hanford Site that contain radioactive and hazardous waste from the reprocessing of irradiated fuel elements beginning in 1944. These underground storage tanks are grouped in 12 tank farms located in the 200 East and West Areas.

There are 133 SSTs classified as 100 series tanks. Tanks in this series are $75 \mathrm{ft}$ in diameter with dome tops. Tank volumes are either $500,000 \mathrm{gal}, 750,000 \mathrm{gal}$, or $1 \mathrm{Mgal}$. These tanks have a minimum of $6 \mathrm{ft}$ of soil cover on the dome and a belowgrade invert elevation of $37 \mathrm{ft}$ to $51 \mathrm{ft}$. The 500,000 gal and 750,000 gal tanks were originally arranged in cascades of three, four, or six tanks such that when the first tank in a cascade filled it overflowed to the next tank, and so on. Tank farms with this arrangement include 241-B, 241-BX, 241-BY, 241-C, 241-S, 241-T, 241-TX, 241-TY, and 241-U. The $1 \mathrm{Mgal}$ tanks are located in the 241-A, 241-AX, and 241-SX tank farms.

The other 16 SSTs are classified as 200 series tanks. These tanks are $20 \mathrm{ft}$ in diameter with flat tops. Tank capacities are all $55,000 \mathrm{gal}$. The tanks all have a minimum of $12 \mathrm{ft}$ of soil cover and a below grade invert elevation of $32 \mathrm{ft}$. The tanks are arranged in groups of four and located in the 241-B, 241-C, 241-T, and 241-U tank farms.

Many of the SSTs have leaked or are assumed to have leaked in the past for various reasons. An interim stabilization program to reduce the waste volumes and remove all SSTs from liquid storage service is ongoing. Free liquid is pumped out to the extent possible to minimize the potential environmental impact in the event of a tank leak. Status of each of the SSTs and estimates of the leaked volumes are provided in WHC (1993b).

\subsubsection{Single-Shell Tank Waste Description}

A total of $37 \mathrm{Mgal}$ of waste is stored in the SSTs. About $600,000 \mathrm{gal}$ is supernatant, 23 Mgal is salt cake, and $12 \mathrm{Mgal}$ is sludge (WHC 1993a). The salt cake consists of the various salts formed from the evaporation of alkaline waste and is approximately $93 \mathrm{wt} \%$ sodium nitrate $\left(\mathrm{NaNO}_{3}\right)$ and sodium nitrite $\left(\mathrm{NaNO}_{2}\right)$. The sludge consists of the solids (hydrous metal oxides) precipitated from the neutralization of acid waste before being transferred to the SSTs. On transfer of the evaporator slurry into the SSTs, some of the salt precipitated with the sludge. As a result, roughly $50 \%$ of the reported sludge volume is salt cake. The liquid solution exists as supernatant and interstitial liquid in the tanks. An estimated $6 \mathrm{Mgal}$ of drainable interstitial liquid is present in the SST salt cake and sludge. 
The SSTs contain primarily inorganic waste, although relatively small amounts of plant solvents were entrained during fuel reprocessing. Also, water-soluble complexing agents and carboxylic acids added in the 221-B Plant fractionation process are in some SST wastes. A listing of all nonradioactive chemicals known to have been used at production plants and support facilities that transferred waste to the SSTs is documented in Inventory of Chemicals Used at Hanford Production Plants and Support Operations (1944-1980), WHC-EP-0172 (Klem 1990). Specific chemicals that may have been transferred to the SSTs and that appear on the "Dangerous Waste Sources List," WAC 173-303-9904, include carbon tetrachloride, methylene chloride, hexone, acetone, and ethyl ether. Chemical reactions (e.g., oxidationreduction, neutralization, precipitation) and radiolysis may have converted many of these chemicals into other compounds with different physical and chemical properties.

Core samples have been taken from relatively few of the 149 SSTs to date. Additional information is needed about the waste properties and composition to evaluate the applicability of the different barrier concepts being considered. The transport of contaminants in the soil column to the groundwater is also dependent on the soil chemistry. The mobility of key waste components varies greatly under different conditions (e.g., alkaline, acidic, or organic). Hanford Federal Facility Agreement and Consent Order (Tri-Party Agreement) (ecology et. al. 1992) milestones have been established for characterizing the contents of the SSTs. Future funding plans give priority to waste characterization efforts.

\subsubsection{Hanford Site Geology}

The geology of the vadose zone beneath the tank farms is highly variable. In the 200 East Area the most important suprabasalt stratigraphic unit underlying the tank farms is the Hanford formation. Hanford formation strata also form an important part of the vadose zone beneath the tank farms in the 200 West Area. However, a significant part of the vadose zone in the 200 West Area also consists of units underlying the Hanford formation, the PlioPleistocene/early Palouse (PP/EP) interval and the Ringold Formation.

Throughout the 200 East and West Areas the Hanford formation is the uppermost stratigraphic unit underlying the tank farms. Hanford formation strata consist of uncemented gravel, sand, and silt deposited by Pleistocene cataclysmic flood waters. The Hanford formation varies from 200- to 300-ft-thick in the 200 East Area to 100- to 150-ft-thick in the 200 West Area. Hanford deposits are divided into three facies that are gradational with each other and summarized as follows:

- Gravel-dominated facies: Generally consists of cross stratified, coarse-grained sand and granule to boulder gravel that contain minor intercalated silt-rich horizons. This facies generally is uncemented and matrix-poor, displays an open-framework texture, and has high saturated hydraulic conductivities. 
- $\quad$ Sand-dominated facies: Well stratified, fine- to coarse-grained sand and granule to pebble gravel dominate. Silt content is variable, but where it is low an openframework texture is common. Lenticular pebble gravel and silt interbeds may be present. Hydraulic conductivity values for this facies are dependant on silt content and as such are variable.

- $\quad$ Silt-dominated facies: Interbedded silt and fine- to coarse-grained sand forming well stratified fining upwards beds are characteristic. Perched water is common where this facies occurs because of the abundance of low hydraulic conductivity silt horizons.

In addition to the three facies, clastic dikes are also commonly found in the Hanford formation as well as locally in other sedimentary units in the Pasco Basin. These clastic dikes are structures that generally cross-cut bedding, although they do locally parallel bedding. The dikes usually consist of thin, alternating vertical to subvertical layers of silt, sand, and granules that can combine to form a dike several feet across. Where the dikes intersect the ground surface a feature known as patterned ground may be observed. Clastic dikes may act as both barriers to lateral flow as well as conduits for vertical flow depending on their composition.

Strata comprising the PP/EP interval and the Ringold Formation form the lower half of the vadose zone in the 200/West Area. In addition, Ringold Formation deposits locally comprise the lowermost few tens of feet of the vadose zone in the 200 East Area. The PP/EP interval underlies the Hanford formation beneath most of the 200 West Area. It is up to approximately 40-ft-thick and consists of (1) lenticular beds of uncemented silt, sand, and gravel, (2) calcium carbonate lenses and concretions, and (3) calcium carbonate and silica cemented sands and gravels. Perched water can occur locally on silt-rich and cemented zones within the PP/EP interval.

Ringold Formation strata in the 200 East and West Areas are dominated by partially consolidated to cemented, clast to matrix supported, pebble to cobble gravels with a fine- to coarse-grained sand matrix. Localized sand-rich intervals also occur in the Ringold Formation. Silt content in Ringold gravels and sands generally is low $(<5 \%)$, although the presence of cementation and local silt-rich zones may produce perched water conditions. About 50 to $90 \mathrm{ft}$ of Ringold strata occur in the vadose zone in the 200 West Area.

\subsection{SYSTEMS ENGINEERING APPROACH}

The functions and requirements for the TWRS Program are provided in the Tank Waste Remediation System Functions and Requirements, DOE/RL-92-60 (RL 1994a). This document was prepared in a manner consistent with DOE/RL-92-60. Appendix A is provided as a convenience for readers who are unfamiliar with the TWRS systems engineering methodology. 


\subsection{FUNCTIONS AND REQUIREMENTS DOCUMENT}

Functions are specific actions or processes that achieve or support the achievement of objectives (i.e., what must be done). Requirements are criteria that set acceptable limits on functions and their products (i.e., how well a function must be performed).

A mission analysis defines the function that a system as a whole must perform. This toplevel function can be decomposed into subfunctions that are both necessary and sufficient to accomplish the mission. Requirements may be general in nature and apply to an entire system, or they may themselves be decomposed and allocated to subfunctions at a lower level.

This document describes the functions to be performed by SST Leakage Mitigation Systems based on their role in supporting remediation of the SSTs, and to identify the requirements that constrain their application. These functions and requirements together define the functional baseline for SST Mitigation Systems. 


\subsection{FUNCTIONS AND REQUIREMENTS}

The functions described herein were decomposed from fourth-level functions as identified in DOE/RL-92-60 Rev. 1, Tank Waste Remediation System Functions and Requirements and three assumed fifth-level functions. The primary sixth-level functions establish general requirements applicable to SST Leakage Mitigation. The seventh-level subfunctions were established to define the baseline and alternative methods in greater detail. The functions, requirements, and interfaces identified below will be used to facilitate further development of alternative design concepts. The functions, requirements, and interfaces will then be further refined as needed to provide a basis for further evaluation.

The TWRS Systems Engineering process will continue as described in DOE/RL-93-0106, Annex 2. As each step in the process is completed, the functions and requirements identified will be evaluated, and revised if necessary, to maintain continuity with the TWRS functions and requirements.

The functions and requirements defined below are intended to focus on function specific items. The general requirements for safe conduct of operations, as low as reasonably achievable (ALARA)/radiation protection, environmental \& regulatory compliance, design of systems, and other items applicable to SST Leakage Mitigation operations in the Hanford Tank Farms are not included to avoid unnecessary repetition. Appendix B to this document provides a summary of the applicable general requirements.

\subsection{FUNCTION HIERARCHY}

Each function identified for SST Leakage Mitigation is given a number of the format 4.2.i.j.k-Mx or -Mx.y. The first part of the number, 4.2.i.j.k, is the number of the assumed TWRS fifth-level function from which the project-level function was decomposed. The "-M" indicates that it is a function allocated to SST Leakage Mitigation. The "x" or "x.y" completes the unique number within each "4.2.i.j.k" group. For example, 4.2.1.1.2-M1 indicates a function decomposed from TWRS function 4.2.1.1.2 and allocated to the SST Leakage Mitigation system; and 4.2.1.1.2-M1.1 indicates a subfunction of 4.2.1.1.2-M1.

Figure 2-1 illustrates the hierarchy of the SST Leakage Mitigation functions, as decomposed from the TWRS fourth-level functions. Figure A-2 in Appendix A of this document shows the hierarchy of the TWRS functions to the fourth level. Table 2-1 provides the requirements allocation and is arranged by requirement. 
Figure 2-1. SST Leakage Mitigation Function Hierarchy.

Lovel 4

\begin{tabular}{|l|l|}
\hline 4.2 .1 .1 & Store Waste \\
\hline
\end{tabular}

Lovel 5

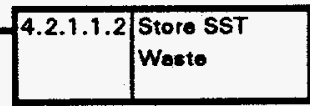

Level 6

\begin{tabular}{|l|l|}
\hline $\begin{array}{l}\text { 4.2.1.1.2- } \\
\text { M1 }\end{array}$ & $\begin{array}{l}\text { Mitigate SST } \\
\text { Leakage During } \\
\text { Storege }\end{array}$ \\
\hline
\end{tabular}

Lovel 7

- 4.2.1.1.2-M1.1 Prevent Now Leakege

4.2.1.1.2-M1.2 Confine Past Lask:

4.2.1.1.2-M1.3 Remove Soil Contamination

4.2.1.1.2-M1.4 Monitor Porf.Nerify Compliance

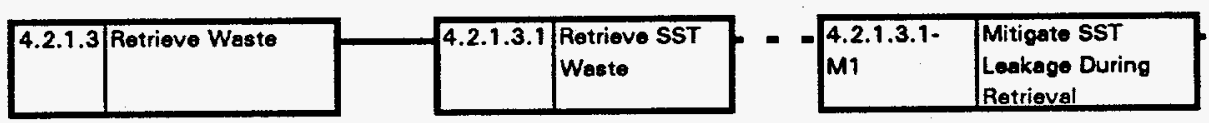

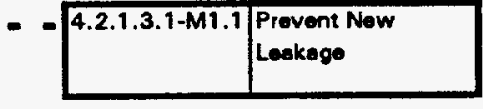

4.2.1.3.1-M1.2 Confine Pest Leaks

4.2.1.3.1-M1.3 Remove Soil Contamination

4.2.1.3.1-M1 .4 Monitor Perf.Nerify Compliance
4.2.1.5 Concentrate Waste

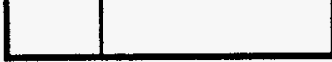

\begin{tabular}{|l|l|}
\hline 4.2 .2 .1 & Pratraat Wasto \\
\hline
\end{tabular}

4.2.2.2 Immabilize

HLW/TRU Wasto

4.2.2.3 Prepare Cs/Sr

Capsules for

Disposal

4.2.2.4 Interim Store $1 \mathrm{HLW}$

\begin{tabular}{|l|l|}
\hline 4.2 .2 .5 & $\begin{array}{l}\text { Interim Store and } \\
\text { Transport ITRU } \\
\text { Waste }\end{array}$ \\
\hline
\end{tabular}

\begin{tabular}{|l|l|l|}
\hline 4.2 .3 .1 & Immobilize \& \\
\hline
\end{tabular} Dispose LLW

4.2.3.2 Disposition Gaseous Effluent

\begin{tabular}{|l|l|}
\hline 4.2 .3 .3 & Disposition Liquid \\
\hline
\end{tabular} Effluent

4.2.3.4 Disposition Solid Waste

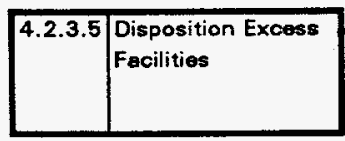

4.2.3.5.2 Remove

Residuel

inventories

\begin{tabular}{|l|l|}
\hline 4.2 .3 .6 & $\begin{array}{l}\text { Disposition } \\
\text { Reusable Materials }\end{array}$ \\
\hline
\end{tabular}

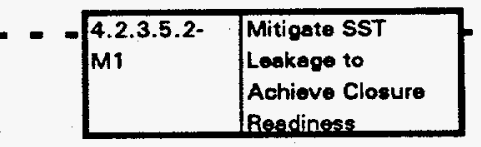

\begin{tabular}{|l|l|}
\hline $4.2 .3 .5 .2-M 1.1$ & Confine Post Leaks \\
& \\
\hline
\end{tabular}

\begin{tabular}{|l|l}
\hline 4.2.3.5.2-M1.2 Remove Soil & \\
\hline
\end{tabular}

Contamination

\begin{tabular}{|l|l|}
\hline 4.2.3.5.2-M1.3 Monitor Perf.Nerify &
\end{tabular}

Compliance 
Table 2-1. SST Leakage Mitigation Requirements Allocation.

\begin{tabular}{|c|c|c|c|}
\hline Requirement & Subject & Function & Interface \\
\hline \multirow[t]{3}{*}{ 40CFR265.196(c)(1) } & \multirow[t]{3}{*}{ Migration of Leaks } & 4.2.1.1.2-M1.2 & TBD \\
\hline & & 4.2.1.3.1-M1.2 & TBD \\
\hline & & $4.2 .3 .5 .2-M 1.1$ & TBD \\
\hline \multirow[t]{3}{*}{ DOE5400.5, Chapter II, 1.d.(3) } & \multirow[t]{3}{*}{ Rx Limits in Groundwater } & 4.2.1.1.2-M1.2 & TBD \\
\hline & & 4.2.1.3.1-M1.2 & TBD \\
\hline & & 4.2.3.5.2-M1.1 & TBD \\
\hline \multirow[t]{3}{*}{ DOE5400.5, Chapter II, 3.c.(2) } & \multirow[t]{3}{*}{ Migration of Leaks } & 4.2.1.1.2-M1.2 & TBD \\
\hline & & 4.2.1.3.1-M1.2 & TBD \\
\hline & & 4.2.3.5.2-M1.1 & TBD \\
\hline \multirow[t]{3}{*}{ DOE5820.2A, Chapter 1, 3.b.(3)(a,c) } & \multirow[t]{3}{*}{ Leak Detection } & 4.2.1.1.2-M1.4 & TBD \\
\hline & & $4.2 .1 .3 .1-M 1.4$ & TBD \\
\hline & & 4.2.3.5.2-M1.3 & TBD \\
\hline \multirow[t]{2}{*}{ DOE5820.2A, Chapter I, 3.b.(4)(b) } & \multirow[t]{2}{*}{ Leak Mitigation } & 4.2.1.1.2-M1 & TBD \\
\hline & & 4.2.1.3.1-M1 & TBD \\
\hline \multirow[t]{3}{*}{ DOE5820.2A, Chapter I, 3.b.(7)(a) } & \multirow[t]{3}{*}{ Waste Minimization } & 4.2.1.1.2-M1 & TBD \\
\hline & & 4.2.1.3.1-M1 & TBD \\
\hline & & 4.2.3.5.2-M1 & TBD \\
\hline \multirow[t]{3}{*}{ PL 101-510, Section 3137, a } & \multirow[t]{3}{*}{ Leak Detection } & 4.2.1.1.2-M1.4 & TBD \\
\hline & & $4.2 .1 .3 .1-M 1.4$ & TBD \\
\hline & & $4.2 .3 .5 .2-M 1.3$ & TBD \\
\hline \multirow[t]{3}{*}{ TPA Change Control Form M-45-00 } & \multirow[t]{3}{*}{ SSB Evaluation } & 4.2.1.1.2-M1 & TBD \\
\hline & & 4.2.1.3.1-M1 & TBD \\
\hline & & 4.2.3.5.2-M1 & TBD \\
\hline TPA Change Control Form M-45-05 & SST Retrieval & 4.2.1.3.1-M1 & TBD \\
\hline TPA Change Control Form M-45-06 & SST Closure & 4.2.3.5.2-M1 & TBD \\
\hline \multirow[t]{3}{*}{ WAC 173-160 } & \multirow[t]{3}{*}{ Well Drilling } & 4.2.1.1.2-M1 & TBD \\
\hline & & 4.2.1.3.1-M1 & TBD \\
\hline & & 4.2.3.5.2-M1 & TBD \\
\hline \multirow[t]{3}{*}{ WAC $173-303$} & \multirow[t]{3}{*}{ Ground water Protection } & 4.2.1.1.2-M1 & TBD \\
\hline & & 4.2.1.3.1-M1 & TBD \\
\hline & & 4.2.3.5.2-MI & TBD \\
\hline \multirow[t]{3}{*}{ WAC $173-340$} & \multirow[t]{3}{*}{ Groundwater Protection } & $4.2 .1 .1 .2-\mathrm{M} 1$ & TBD \\
\hline & & $4.2 .1 .3 .1-M 1$ & TBD \\
\hline & & 4.2.3.5.2-M1 & TBD \\
\hline WAC 173-303-610(2)(a) & Closure Performance & $4.2 .3 .5 .2-\mathrm{M} 1$ & TBD \\
\hline WAC 173-303-640 (8) & Tank System Closure & $4.2 .3 .5 .2-M 1$ & TBD \\
\hline \multirow[t]{3}{*}{ WHC-CM-4-11 } & \multirow[t]{3}{*}{ Rad. Protection } & 4.2.1.1.2-M1 & TBD \\
\hline & & 4.2.1.3.1-M1 & TBD \\
\hline & & 4.2.3.5.2-M1 & TBD \\
\hline WHC-OSD-T-151-00013, Section 13.2.1, C(2) & Tank Dome Loading & $4.2 .1 .1 .2-\mathrm{M} 1$ & TBD \\
\hline & & $4.2 .1 .3 .1-M 1$ & TBD \\
\hline & & $4.2 .3 .5 .2-\mathrm{M} 1$ & TBD \\
\hline WHC-OSD-T-151-00013, Section 13.2.1, E(1) & Temperature of Concrete & $4.2 .1 .1 .2-\mathrm{M} 1$ & TBD \\
\hline & & 4.2.1.3.1-M1 & TBD \\
\hline & & $4.2 .3 .5 .2-\mathrm{M1}$ & TBD \\
\hline
\end{tabular}




\subsection{FUNCTION DESCRIPTION SHEETS}

A Function Description Sheet is provided for each of the functions identified for SST Leakage Mitigation. The Function Description Sheets provide the function definitions, enabling assumptions, interfaces, function requirements, and interface requirements. The sheets were prepared according to the format used in DOE/RL-92-60, as shown in Appendix A.

The SST Leakage Mitigation functions and requirements include discussion of the TWRS Program baseline approach as well as several alternatives that are under evaluation per TPA Milestone M-45-07A, (September 1994) "Complete Evaluation of Sub-surface Barrier Feasibility". The function description sheets provide discussion of performance requirements for these "Preferred Alternatives" to establish a basis for evaluation. It is important to note that these performance requirements are not actually part of the TWRS Program but would be applied only if the given alternative was actually implemented. Also, the designation "Preferred Alternative" does not imply that the given alternative is more desirable than the TWRS Program baseline; rather, it implies that the given alternative is considered the most viable out of a group of previously considered alternatives. 
I. FUNCTION ID NUMBER: 4.2.1.1.2-M1

II. FUNCTION TITLE: Mitigate SST Leakage During Storage

III. FUNCTION DEFINITION:

Mitigate SST leakage during waste storage activities as required. Applicable to leakage plumes resulting from past operations and those that may result from new leaks.

IV. ENABLING ASSUMPTIONS:

Existing waste will continue to be stored in existing tanks. Decomposition of Function 4.2.1.1 will include the fifth-level function "Store SST waste."

\section{INTERFACES}

\section{A. INPUTS}

\subsubsection{2-M1 I1 Single-Shell Tank Farms}

From: External

SST farms - including the tanks, ancillary systems (e.g., transfer lines, dry wells, groundwater monitoring wells, other above or belowground hardware), soil contamination plumes resulting from past or new leaks.

\subsubsection{2-M1 I2 SST Leakage Characterization Data}

From: 4.2 .1 .2

Information about SST leakage and soil contamination plumes.

\subsubsection{2-M1 I3 SST Waste Characterization Data}

From: 4.2 .1 .2

Information about the constituents of the waste in each tank.

\subsubsection{2-B1 I4 SST Integrity Data}

From: 4.2 .1 .1

Information about the structural integrity of SSTs, including maximum and minimum allowable loads and temperatures.

\subsubsection{2-B1 I5 Tank Farm Geological Data}

From: 4.2.1.2

Information about the tank farm geology, including soil properties, lithography, history, and hydrology. 


\section{B. OUTPUTS}

\subsubsection{2-M1 O1 Liquid Effluent}

To: 4 2.3.3

Liquid effluent streams resulting from SST leakage mitigation operations for treatment and disposal.

\subsubsection{2-M1 O2 Solid Waste}

To: 4.2 .3 .4

Solid waste generated from SST leakage mitigation system operations.

\subsubsection{2-M1 O3 Gaseous Effluent}

To: 4.2 .3 .2

Offgas streams resulting from SST leakage mitigation system operations for treatment and disposal.

\subsubsection{2-M1 O4 Excess Equipment/Facilities}

To: 4 2.2.3.5

SST leakage mitigation system components, once they are no longer needed in fulfillment of the TWRS mission.

\subsubsection{2-M1 O5 Reusable Materials}

To: 4.2 .3 .6

Materials economically suitable for reuse by TWRS or other programs.

\section{FUNCTION REQUIREMENTS}

\section{A. Performance Requirements}

4.2.1.1.2-M1 P1 Mitigate leakage from SSTs in a manner that supports tank farm SST waste storage activities and overall SST remediation objectives. The TWRS Program baseline approach is to take no action to mitigate SST leakage during waste storage activities. In effect, this approach would utilize the tank farm vadose zone soil as a natural barrier to inhibit flow of any leaked contaminants to the environment. Subsurface barriers and other alternatives for mitigating SST leakage that may result from storage activities will be evaluated per TPA Milestone M-45-07A, (September 1994) "Complete Evaluation of Sub-surface Barrier Feasibility". 


\section{B. Constraints}

4.2.1.1.2-M1 C1 (b) Upon detection of released radioactive materials, steps shall be taken to prevent further migration of the release to soil or surface water. Major contamination in the soil shall be removed or stabilized unless compliance with this requirement would cause greater harm to human health or the environment.

[DOE5820.2A, Chapter I, 3.b.(4)(b)]

4.2.1.1.2-M1 C2 Waste Minimization. The quantity of waste being sent to storage shall be reduced. Basis: Significant volumes of radioactive solid waste may be generated as a result of barrier installation, operation, and (if needed) removal.

[DOE Order 5820.2A, Chapter I, 3b(7)(a)]

4.2.1.1.2-M1 C3 M-45-07 (September 1997) Complete Evaluation and Demonstration Testing of Sub-scale Barriers

DOE will assess the risk to the environment due to tank waste remediation. DOE with concurrence from Ecology and EPA will evaluate barrier technology as a means to minimize those risks and vendor capabilities to deploy and test barriers in Hanford soils. Retrieval of waste from tank 241-C-106 will proceed without a barrier.

M-45-07A (September 1994) Complete Evaluation of Sub-surface Barrier Feasibility

Complete a feasibility study of barriers to accomplish the following:

1) Estimate the potential environmental impact of waste storage and retrieval activities without the application of barriers.

2) Establish functional requirements of barriers to minimize the impact associated with the waste storage and retrieval activities.

3) Evaluate the application of existing sub-surface barrier technologies to meet functional requirements of barriers and the potential reduction in environmental impacts from the application of barriers to SST waste storage and retrieval activities.

M-45-07B (January 1995) Reach Decision on Whether to Proceed with Demonstration

Based on the results of the sub-surface barrier feasibility study, Ecology, EPA, and DOE will make a decision on whether to proceed with a sub-scale demonstration. If the decision is negative, then interim milestone $\mathrm{M}-45-07$ will be considered complete.

M-45-07-T1 (March 1995) Establish Performance Criteria and Test Specifications 
Ecology, EPA, and DOE establish and reach agreement on performance criteria and test specifications to be used for the sub-Scale demonstration of sub-surface barrier technologies.

M-45-07-T2 (October 1995) Initiate Demonstration Testing of Selected Sub-Surface Barrier Technologies

Sub-scale testing of one or more sub-surface barrier technologies will be initiated at a Hanford test site. Documentation will be completed prior to testing which will incorporate performance criteria and test specifications. Initiation of demonstration is defined as completion of construction and initiation of test procedures.

M-45-07-T3 (March 1997) Complete Evaluation of Sub-Surface Barrier Demonstration Test Results

Test data and related information will be provided to Ecology, EPA, and DOE as it becomes available during testing. Sub-surface barrier technologies will be evaluated against the performance criteria and test specifications.

M-45-07-T4 (June 1997) Reach Decision on Whether to Proceed with Sub-Surface Barrier Program

Ecology, EPA, and DOE will make a decision on whether to proceed with installation of a full-scale sub-surface barrier to support SST retrieval under milestone M-45-07. If the decision is negative, then milestone M-45-07 will be considered complete.

M-45-07C (September 1997) Establish New Milestones for Sub-Surface Barrier Implementation

Ecology, EPA, and DOE will negotiate and reach agreement on new milestones to support milestone M-45-07 and a program to install sub-surface barriers in SST farms or individual tanks to support SST retrieval schedules under M-45-00. New milestones will include completion of construction of construction of a full-scale subsurface barrier in a tank farm, in conjunction with the installation of the retrieval systems pursuant to M-45-04-T3 (complete construction for the initial SST retrieval systems).

[TPA Change Control Form M-45-00]

4.2.1.1.2-M1 C4 Well Drilling. Monitoring wells and other bore holes shall be appropriately sealed after use so as to not provide a pathway for contamination to the groundwater. Basis: Barrier installation will likely involve some type of drilling (e.g., vertical, angle, or horizontal bore holes).

[WAC 173-160] 
4.2.1.1.2-M1 C5 Groundwater Protection. Groundwater protection standards applicable to the Hanford single and double shell radioactive waste storage tanks can be divided into two categories: those applicable during tank operations and the closure period, and those that must ultimately be met to achieve closure.

Under Chaper 173-303 of Washington Administrative Code (WAC), concentrations of dangereous waste constituents regulated by Chapter 173-303 WAC in the groundwater beneath an active treatment, storage or disposal (TSD) facility, or a TSD facility undergoing closure, must not exceed local background levels or, for the toxicity characteristic (TC) metals and pesticides, a concentration $1 / 100$ the toxicity characteristic concentration for designation as a dangerous waste listed in WAC 173303-090 (these actual concentrations are tabulated in WAC 173-303-645). These limits could technically apply during the postclosure period for any unit where a clean closure is not achieved; however, it is more likely that any postclosure limits will be established consistent with the overall strategy for groundwater protection and remediation at the Hanford Site, as described below.

Due to the long travel times for contaminants to reach the aquifers underlying the Hanford Site, it is unlikely that a release from a tank TSD unit during the closure period (e.g., while wastes are being removed from the tank) would reach the water table and cause these "operational" groundwater limits to be exceeded. Furthermore, groundwater contamination at the Hanford Site is an extremely complex problem, with interactions between numerous contributing operable units that are undergoing remediation and closure under both the CERCLA and RCRA programs. It is likely that the Hanford Site will adopt a strategy of remediating all groundwater contamination to levels consistent with the goals of the CERCLA and RCRA programs, as well as related NRC guidance. Both Chapter 173-303 WAC and the CERCLA ARARs process are likely to establish cleanup/closure levels based on the health-risk based concentrations established under Chapter 173-340 WAC, the Model Toxics Control Act (MTCA) implementing regulation. The MTCA Method B cleanup standards have been incorporated into Chapter 173-303 WAC by reference as the appropriate clean closure and corrective action standards for RCRA TSD units in Washington State. The MTCA standards are also explicitly called out as ARARs for the Hanford Site under the Tri Party Agreement. Therefore, it is likely that the ultimate groundwater protection standard established for the tank waste remediation program will be based on a demonstration that releases will not cause the MTCA standards to be exceeded at any time.

Under MTCA, groundwater cleanup levels are set so as to ensure that the total toxic constituents do not exceed a Health Index (HI) of 1 , and that carcinogenic substance concentrations do not cause a carcinogenic risk greater than $10^{-6}$ (Method B) or $10^{-5}$ (Method C). Soil cleanup standards protective of groundwater are set at a level 100 times the groundwater protection standard as a default; this level may be adjusted through a site-specific evaluation of contaminant fate and transport. These health-risk 
based levels are consistent with the range of uniform cleanup standards under consideration by the NRC and EPA for sites containing radioactive contaminants

The following table provides MTCA Method B and C standards for the eight compounds identified in ongoing evaluations as the risk drivers for waste tank remediation, due to their relatively high mobility in the Hanford Site environment. These concentrations assume that the only exposure pathway is through ingestion of contaminated groundwater; other exposure pathways (e.g., inhalation of contaminated groundwater through showering) are not considered. In instances where the maximum contaminant level (MCL) is lower than the calculated MTCA Method B and $\mathrm{C}$ levels, the MCL has been used. The calculations assume a 30 year exposure period over which $2 \mathrm{~L} /$ day of contaminated groundwater is ingested, and a 75 year lifetime, and an average body weight of $16 \mathrm{~kg}$ (non-carcinogens) or $70 \mathrm{~kg}$ (carcinogens). These standards also assume that each constituent is the only hazardous material present; for mixtures of constituents, a weighted contribution calculation must be performed (e.g., the sum of the concentrations for each non-carcinogenic constituent divided by the values for each of these constituents listed below must be less than 1).

Groundwater Protection Standards for Hanford Site Tank Waste Remediation.

\begin{tabular}{|c|c|c|c|c|}
\hline Contaminant & $\begin{array}{c}\text { MTCA } \\
\text { Method B } \\
\text { for } \\
\text { Groundwater } \\
\\
(\mathrm{mg} / \mathrm{L})\end{array}$ & $\begin{array}{c}\text { MTCA } \\
\text { Method C } \\
\text { for } \\
\text { Groundwater } \\
\\
(\mathrm{mg} / \mathrm{L})\end{array}$ & $\begin{array}{c}\text { MTCA Soils } \\
\text { (based on } \\
\text { Method B } \\
\text { Groundwater) } \\
\text { (mg/kg) }\end{array}$ & $\begin{array}{c}\text { MTCA Soils } \\
\text { (based on } \\
\text { Method C } \\
\text { Groundwater) } \\
\text { (mg } / \mathrm{kg})\end{array}$ \\
\hline $\begin{array}{l}\text { EDTA (non- } \\
\text { carcinogen) }\end{array}$ & 0.021 & 0.046 & 2.1 & 4.6 \\
\hline $\begin{array}{l}\text { Nitrate (non- } \\
\text { carcinogen) }\end{array}$ & $10^{*}$ & --.- & $1000^{*}$ & ---- \\
\hline $\begin{array}{l}\text { Nitrite (non- } \\
\text { carcinogen) }\end{array}$ & $1 *$ & ---- & $100 *$ & $\cdots$ \\
\hline TBP (carcinogen) & 0.011 & 0.11 & 1.1 & 11.0 \\
\hline & $(\mathrm{pCi} / \mathrm{L})$ & $(\mathrm{pCi} / \mathrm{L})$ & $(\mathrm{pCi} / \mathrm{kg})$ & $(\mathrm{pCi} / \mathrm{kg})$ \\
\hline C-14 (carcinogen) & 51 & 510 & 5100 & 51000 \\
\hline $\begin{array}{l}\text { Tc-99 } \\
\text { (carcinogen) }\end{array}$ & 35 & 350 & 3500 & 35000 \\
\hline I-129 (carcinogen) & 0.24 & 2.4 & 24 & 240 \\
\hline $\begin{array}{l}\mathrm{U}-238 \\
\text { (carcinogen) }\end{array}$ & 1.6 & 16.0 & 160 & 1600 \\
\hline
\end{tabular}


4.2.1.1.2-M1 C6 Radiation Protection. The "as low as reasonably achievable" (ALARA) guideline in WHC-CM-4-11 shall be implemented in the design of equipment, components, or assemblies, and in the planning of construction, installation, operation, maintenance, and decommissioning activities. Evaluations and cost-benefit analyses for determining that the radiation exposure levels are ALARA shall used the methodologies established in International Commission on Radiological Protection 37, "Cost-Benefit Analysis in the Optimization of Radiation Protection."

4.2.1.1.2-M1 C7 Tank Dome Loading. Total live loads on the tank dome are limited to a maximum of 50 tons for $20-\mathrm{ft}$ diameter tanks, and 100 tons for $75-\mathrm{ft}$ diameter tanks. These loads are assumed to occur on the soil covering the tank within a 10-ft radius of the tank center. Loads in excess of these shall be evaluated on a case-bycase basis and require approval by Single-Shell Tank Process Engineering and Tank Farm Operations. Loads imposed during barrier installation and operation, and other loads (e.g., waste retrieval equipment) shall be considered.

[OSD-T-151-00013, Revision D-1, Section 13.2.1, C(2)]

4.2.1.1.2-M1 C8 Temperature of Concrete Encasement. The temperature of the concrete encasement during barrier installation and operation is limited to a maximum of $250^{\circ} \mathrm{F}$ (HOLD). The rate of temperature change is limited to a maximum of $20^{\circ} \mathrm{F} /$ day (HOLD). Basis: Temperature limits are set to prevent structural damage to the tank which could cause the tank to leak.

[OSD-T-151-00013, Revision D-1, Section 13.2.1, E(1)]

\section{INTERFACE REQUIREMENTS}

See Section 4.0 for requirements allocated to the interfaces of this function. 


\section{FUNCTION ID NUMBER: 4.2.1.1.2-M1.1}

II. FUNCTION TITLE: Prevent New Leakage from SSTs

III. FUNCTION DEFINITION:

Prevent or minimize new SST leakage during waste storage activities per actions agreed upon with DOE-RL, Ecology, and EPA.

IV. ENABLING ASSUMPTIONS:

Existing waste will continue to be stored in existing tanks. Decomposition of Function 4.2.1.1 will include the fifth-level function "Store SST waste."

V. INTERFACES

A. INPUTS

Same as 4.2.1.1.2-M1

B. OUTPUTS

Same as 4.2.1.1.2-M1

VI. FUNCTION REQUIREMENTS

Same as 4.2.1.1.2-M1

VII. INTERFACE REQUIREMENTS

See Section 4.0 for requirements allocated to the interfaces of this function. 
I. FUNCTION ID NUMBER: 4.2.1.1.2-M1.2

II. FUNCTION TITLE: Confine Past Leaks

III. FUNCTION DEFINITION:

Confine past SST leakage during waste storage activities per actions agreed upon with DOE-RL, Ecology, and EPA.

IV. ENABLING ASSUMPTIONS:

Existing waste will continue to be stored in existing tanks. Decomposition of Function 4.2.1.1 will include the fifth-level function "Store SST waste."

\section{INTERFACES}

\section{A. INPUTS}

Same as 4.2.1.1.2-M1

\section{B. OUTPUTS}

Same as 4.2.1.1.2-M1

VI. FUNCTION REQUIREMENTS

A. Performance Requirements

Same as 4.2.1.1.2-M1

B. Constraints

4.2.1.1.2-M1.2 C1 Migration of Leaks. For tank systems in interim status from which there has been a leak, the owner or operator must prevent further migration of the leak or spill to soils or surface water.

[40CFR265, Section 265.196(c)(1)]

4.2.1.1.2-M1.2 C2 Radionuclide Limits in Groundwater. The liquid effluents from DOE activities shall not cause private or public drinking water systems downstream of the facility discharge to exceed the drinking water radiological limits of 40 CFR 141 . These systems shall not cause persons consuming the water to receive an effective dose equivalent greater than $4 \mathrm{mrem} / \mathrm{yr}$. Combined ${ }^{226} \mathrm{Ra}$ and ${ }^{228} \mathrm{Ra}$ shall not exceed $5 \mathrm{E}-09 \mu \mathrm{Ci} / \mathrm{mL}$ and gross $\alpha$ activity (including ${ }^{226} \mathrm{Ra}$ but excluding radon and uranium) shall not exceed $1.5 \mathrm{E}-08 \mu \mathrm{Ci} / \mathrm{mL}$. 
4.2.1.1.2-M1.2 C3 Migration of Leaks. Liquid discharges, even though uncontaminated, are prohibited in inactive release areas to prevent the further spread of radionuclides previously deposited, unless the discharge is part of an interim or final cleanup response.

[DOE5400.5, Chapter II, 3c(2)]

\section{INTERFACE REQUIREMENTS}

See Section 4.0 for requirements allocated to the interfaces of this function. 
I. FUNCTION ID NUMBER: 4.2.1.1.2-M1.3

II. FUNCTION TITLE: Remove Soil Contamination

III. FUNCTION DEFINITION:

Remove soil contamination resulting from SST leakage during storage per actions agreed upon with DOE-RL, Ecology, and EPA.

IV. ENABLING ASSUMPTIONS:

Existing waste will continue to be stored in existing tanks. Decomposition of Function 4.2.1.1 will include the fifth-level function "Store SST waste."

V. INTERFACES

A. INPUTS

Same as 4.2.1.1.2-M1

B. OUTPUTS

Same as 4.2.1.1.2-M1

VI. FUNCTION REQUIREMENTS

Same as 4.2.1.1.2-M1

VII. INTERFACE REQUIREMENTS

See Section 4.0 for requirements allocated to the interfaces of this function. 
I. FUNCTION ID NUMBER: 4.2.1.1.2-M1.4

II. FUNCTION TITLE: Monitor Performance and Verify Compliance of Leakage Mitigation System

III. FUNCTION DEFINITION:

Monitor performance and verify compliance of leakage mitigation system during storage to the extent needed and per actions agreed upon with DOE-RL, Ecology, and $E P A$.

IV. ENABLING ASSUMPTIONS:

Existing waste will continue to be stored in existing tanks. Decomposition of Function 4.2.1.1 will include the fifth-level function "Store SST waste."

V. INTERFACES

A. INPUTS

Same as 4.2.1.1.2-M1

B. OUTPUTS

Same as 4.2.1.1.2-M1

VI. FUNCTION REQUIREMENTS

A. Performance Requirements

Same as 4.2.1.1.2-M1

B. Constraints

4.2.1.1.2-M1.4 C1 Leak Detection. Monitoring and leak detection capability shall be incorporated in engineering systems to provide rapid identification of leaks and to assess system integrity.

[DOE5820.2A, Chapter I, 3b(3)(a,c)]

4.2.1.1.2-M1.4 C2 Defense Authorization Act, "Safety Measures for Waste Tanks at Hanford Nuclear Reservation," Section 3137 (also known as the Wyden Amendments). [Para a, Ensure that "...continuous monitoring to detect a release or excessive temperature or pressure..." is being carried out.]

[Public Law 101-510, Section 3137, (a)] 


\section{INTERFACE REQUIREMENTS}

See Section 4.0 for requirements allocated to the interfaces of this function. 


\section{FUNCTION ID NUMBER: 4.2.1.3.1-M1}

II. FUNCTION TITLE: Mitigate SST Leakage During Retrieval

III. FUNCTION DEFINITION:

Mitigate SST leakage during waste retrieval activities as required. Applicable to leakage plumes resulting from past operations and those that result from new leaks.

IV. ENABLING ASSUMPTIONS:

Decomposition of Function 4.2.1.3 will include the fifth-level function "Retrieve SST waste."

V. INTERFACES

A. INPUTS

\subsubsection{1-M1 I1 Single-Shell Tank Farms}

From: External

SST farms - including the tanks, ancillary systems (e.g., transfer lines, dry wells, groundwater monitoring wells, other above or belowground hardware), soil contamination plumes resulting from past or new leaks.

\subsubsection{1-M1 I2 SST Leakage Characterization Data}

From: 4.2.1.2

Information about SST leakage and soil contamination plumes.

\subsubsection{1-M1 I3 SST Waste Characterization Data}

From: 4.2.1.2

Information about the constituents of the waste in each tank.

\subsubsection{1-M1 I4 SST Integrity Data}

From: 4.2 .1 .1

Information about the structural integrity of SSTs, including maximum and minimum allowable loads and temperatures.

\subsubsection{1-B1 I5 Tank Farm Geological Data}

From: 4.2.1.2

Information about the tank farm geology, including soil properties, lithography, history, and hydrology. 


\section{B. OUTPUTS}

\subsubsection{1-M1 O1 Liquid Effluent}

To: 4.2 .3 .3

Liquid effluent streams resulting from SST leakage mitigation operations for treatment and disposal.

\subsubsection{1-M1 O2 Solid Waste}

To: 4.2 .3 .4

Solid waste generated from SST leakage mitigation system operations.

\subsubsection{1-M1 O3 Gaseous Effluent}

To: 4.2 .3 .2

Offgas streams resulting from SST leakage mitigation system operations for treatment and disposal.

\subsubsection{1-M1 O4 Excess Equipment/Facilities}

To: 4.2 .3 .5

SST leakage mitigation system components, once they are no longer needed in fulfillment of the TWRS mission.

\subsubsection{1-M1 O5 Reusable Materials}

To: 4 2.3.6

Materials economically suitable for reuse by TWRS or other programs.

\section{FUNCTION REQUIREMENTS}

\section{A. Performance Requirements}

\section{Baseline}

4.2.1.3.1-M1 P1 Mitigate leakage from SSTs in a manner that supports tank farm SST waste retrieval activities and overall SST remediation objectives. The TWRS Program baseline approach is to take no action to mitigate SST leakage during waste retrieval. In effect, this approach would utilize the tank farm vadose zone soil as a natural barrier to inhibit flow of any leaked contaminants to the environment. Subsurface barriers and other alternatives for mitigating SST leakage that may result from retrieval activities will be evaluated per TPA Milestone M-45-07A, (September 1994) "Complete Evaluation of Sub-surface Barrier Feasibility".

\section{Preferred Alternative - Close-coupled Barriers}

4.2.1.3.1-M1 PA1 Install close-coupled subsurface barriers with associated monitoring systems prior to retrieval on SSTs suspected of having the potential to 
leak. Initial evaluations have identified the use of close-coupled barriers as a potentially cost-effective method to prevent leakage during retrieval and thereby minimize environmental impact.

\subsubsection{1-M1 PA1 Issue 1}

The applicability and effectiveness of close-coupled subsurface barriers as an alternative will be greatly dependant on the general closure philosophy applied to the tank farms (i.e., landfill closure, vs. clean closure).

\subsubsection{1-M1 PA1 Issue 1 Required Analysis}

The designation of the 200 Area as a limited use area has not been accepted by all stakeholder groups and may be subject to challenge.

[DOE/RL-92-60, Table F4.2, Item 4.2 P1 Issue 1]

In conjunction with the Hanford Site Systems Engineering Functions and Requirements analysis, develop interface requirements for these items. A preliminary closure strategy and preliminary performance assessment for SSTs/DSTs may be required to establish interface requirements for the residual waste remaining in the tanks.

[DOE/RL-92-60, Table F4.2, Item 4.2 O3 Issue 1]

4.2.1.3.1-M1 PA2 Installation, operation and maintenance of the subsurface barrier shall be non-controlling and shall support tank farm SST waste retrieval activities and overall SST remediation objectives.

\section{B. Constraints}

4.2.1.3.1-M1 C1 (b) Upon detection of released radioactive materials, steps shall be taken to prevent further migration of the release to soil or surface water. Major contamination in the soil shall be removed or stabilized unless compliance with this requirement would cause greater harm to human health or the environment.

[DOE5820.2A, Chapter I, 3.b.(4)(b)]

4.2.1.3.1-M1 C2 Waste Minimization. The quantity of waste being sent to storage shall be reduced. Basis: Significant volumes of radioactive solid waste may be generated as a result of barrier installation, operation, and (if needed) removal. [DOE Order 5820.2A, Chapter I, 3b(7)(a)]

4.2.1.3.1-M1 C3 M-45-07 (September 1997) Complete Evaluation and Demonstration Testing of Sub-scale Barriers

DOE will assess the risk to the environment due to tank waste remediation. DOE with concurrence from Ecology and EPA will evaluate barrier technology as a means 
to minimize those risks and vendor capabilities to deploy and test barriers in Hanford soils. Retrieval of waste from tank 241-C-106 will proceed without a barrier.

M-45-07A (September 1994) Complete Evaluation of Sub-surface Barrier Feasibility

Complete a feasibility study of barriers to accomplish the following:

1) Estimate the potential environmental impact of waste storage and retrieval activities without the application of barriers.

2) Establish functional requirements of barriers to minimize the impact associated with the waste storage and retrieval activities.

3) Evaluate the application of existing sub-surface barrier technologies to meet functional requirements of barriers and the potential reduction in environmental impacts from the application of barriers to SST waste storage and retrieval activities.

M-45-07B (January 1995) Reach Decision on Whether to Proceed with Demonstration

Based on the results of the sub-surface barrier feasibility study, Ecology, EPA, and DOE will make a decision on whether to proceed with a sub-scale demonstration. If the decision is negative, then interim milestone $\mathrm{M}-45-07$ will be considered complete.

M-45-07-T1 (March 1995) Establish Performance Criteria and Test Specifications

Ecology, EPA, and DOE establish and reach agreement on performance criteria and test specifications to be used for the sub-Scale demonstration of sub-surface barrier technologies.

M-45-07-T2 (October 1995) Initiate Demonstration Testing of Selected Sub-Surface Barrier Technologies

Sub-scale testing of one or more sub-surface barrier technologies will be initiated at a Hanford test site. Documentation will be completed prior to testing which will incorporate performance criteria and test specifications. Initiation of demonstration is defined as completion of construction and initiation of test procedures.

M-45-07-T3 (March 1997) Complete Evaluation of Sub-Surface Barrier Demonstration Test Results

Test data and related information will be provided to Ecology, EPA, and DOE as it becomes available during testing. Sub-surface barrier technologies will be evaluated against the performance criteria and test specifications. 
M-45-07-T4 (June 1997) Reach Decision on Whether to Proceed with Sub-Surface Barrier Program

Ecology, EPA, and DOE will make a decision on whether to proceed with installation of a full-scale sub-surface barrier to support SST retrieval under milestone M-45-07. If the decision is negative, then milestone M-45-07 will be considered complete.

M-45-07C (September 1997) Establish New Milestones for Sub-Surface Barrier Implementation

Ecology, EPA, and DOE will negotiate and reach agreement on new milestones to support milestone M-45-07 and a program to install sub-surface barriers in SST farms or individual tanks to support SST retrieval schedules under M-45-00. New milestones will include completion of construction of construction of a full-scale subsurface barrier in a tank farm, in conjunction with the installation of the retrieval systems pursuant to M-45-04-T3 (complete construction for the initial SST retrieval systems).

[TPA Change Control Form $M-45-00]$

4.2.1.3.1-M1 C4 M-45-05 (September 2018) Retrieve Waste from all Remaining Single-Shell Tanks

Complete waste retrieval form all remaining single-shell tanks. Retrieval standards and completion definitions are provided under the major milestone. The schedule reflects retrieval activities on a farm-by-farm basis. It also allows flexibility to retrieve tanks from various farms if desired to support safety issue resolution, pretreatment or disposal feed requirements, or other priorities.

[TPA Change Control Form M-45-05]

4.2.1.3.1-M1 C5 Well Drilling. Monitoring wells and other bore holes shall be appropriately sealed after use so as to not provide a pathway for contamination to the groundwater. Basis: Barrier installation will likely involve some type of drilling (e.g., vertical, angle, or horizontal bore holes).

[WAC 173-160]

4.2.1.3.1-M1 C6 Groundwater Protection. Groundwater protection standards applicable to the Hanford single and double shell radioactive waste storage tanks can be divided into two categories: those applicable during tank operations and the closure period, and those that must ultimately be met to achieve closure.

Under Chaper 173-303 of Washington Administrative Code (WAC), concentrations of dangereous waste constituents regulated by Chapter 173-303 WAC in the groundwater beneath an active treatment, storage or disposal (TSD) facility, or a TSD facility undergoing closure, must not exceed local background levels or, for the toxicity characteristic (TC) metals and pesticides, a concentration $1 / 100$ the toxicity 
characteristic concentration for designation as a dangerous waste listed in WAC 173303-090 (these actual concentrations are tabulated in WAC 173-303-645). These limits could technically apply during the postclosure period for any unit where a clean closure is not achieved; however, it is more likely that any postclosure limits will be established consistent with the overall strategy for groundwater protection and remediation at the Hanford Site, as described below.

Due to the long travel times for contaminants to reach the aquifers underlying the Hanford Site, it is unlikely that a release from a tank TSD unit during the closure period (e.g., while wastes are being removed from the tank) would reach the water table and cause these "operational" groundwater limits to be exceeded. Furthermore, groundwater contamination at the Hanford Site is an extremely complex problem, with interactions between numerous contributing operable units that are undergoing remediation and closure under both the CERCLA and RCRA programs. It is likely that the Hanford Site will adopt a strategy of remediating all groundwater contamination to levels consistent with the goals of the CERCLA and RCRA programs, as well as related NRC guidance. Both Chapter 173-303 WAC and the CERCLA ARARs process are likely to establish cleanup/closure levels based on the health-risk based concentrations established under Chapter 173-340 WAC, the Model Toxics Control Act (MTCA) implementing regulation. The MTCA Method B cleanup standards have been incorporated into Chapter 173-303 WAC by reference as the appropriate clean closure and corrective action standards for RCRA TSD units in Washington State. The MTCA standards are also explicitly called out as ARARs for the Hanford Site under the Tri Party Agreement. Therefore, it is likely that the ultimate groundwater protection standard established for the tank waste remediation program will be based on a demonstration that releases will not cause the MTCA standards to be exceeded at any time.

Under MTCA, groundwater cleanup levels are set so as to ensure that the total toxic constituents do not exceed a Health Index (HI) of 1 , and that carcinogenic substance concentrations do not cause a carcinogenic risk greater than $10^{-6}$ (Method B) or $10^{-5}$ (Method C). Soil cleanup standards protective of groundwater are set at a level 100 times the groundwater protection standard as a default; this level may be adjusted through a site-specific evaluation of contaminant fate and transport. These health-risk based levels are consistent with the range of uniform cleanup standards under consideration by the NRC and EPA for sites containing radioactive contaminants

The following table provides MTCA Method B and C standards for the eight compounds identified in ongoing evaluations as the risk drivers for waste tank remediation, due to their relatively high mobility in the Hanford Site environment. These concentrations assume that the only exposure pathway is through ingestion of contaminated groundwater; other exposure pathways (e.g., inhalation of contaminated groundwater through showering) are not considered. In instances where the maximum contaminant level (MCL) is lower than the calculated MTCA Method B and $\mathrm{C}$ levels, the MCL has been used. The calculations assume a 30 year exposure period 
over which $2 \mathrm{~L} /$ day of contaminated groundwater is ingested, and a 75 year lifetime, and an average body weight of $16 \mathrm{~kg}$ (non-carcinogens) or $70 \mathrm{~kg}$ (carcinogens). These standards also assume that each constituent is the only hazardous material present; for mixtures of constituents, a weighted contribution calculation must be performed (e.g., the sum of the concentrations for each non-carcinogenic constituent divided by the values for each of these constituents listed below must be less than 1).

Groundwater Protection Standards for Hanford Site Tank Waste Remediation.

\begin{tabular}{|c|c|c|c|c|}
\hline Contaminant & $\begin{array}{c}\text { MTCA } \\
\text { Method B } \\
\text { for } \\
\text { Groundwater } \\
\\
(\mathrm{mg} / \mathrm{L})\end{array}$ & $\begin{array}{c}\text { MTCA } \\
\text { Method C } \\
\text { for } \\
\text { Groundwater } \\
\\
(\mathrm{mg} / \mathrm{L})\end{array}$ & $\begin{array}{c}\text { MTCA Soils } \\
\text { (based on } \\
\text { Method B } \\
\text { Groundwater) } \\
(\mathrm{mg} / \mathrm{kg})\end{array}$ & $\begin{array}{c}\text { MTCA Soils } \\
\text { (based on } \\
\text { Method C } \\
\text { Groundwater) } \\
\text { (mg } / \mathrm{kg})\end{array}$ \\
\hline $\begin{array}{l}\text { EDTA (non- } \\
\text { carcinogen) }\end{array}$ & 0.021 & 0.046 & 2.1 & 4.6 \\
\hline $\begin{array}{l}\text { Nitrate (non- } \\
\text { carcinogen) }\end{array}$ & $10^{*}$ & ---- & $1000^{*}$ & $-\cdots$ \\
\hline $\begin{array}{l}\text { Nitrite (non- } \\
\text { carcinogen) }\end{array}$ & $1 *$ & ----- & $100 *$ & $\cdots$ \\
\hline TBP (carcinogen) & 0.011 & 0.11 & 1.1 & 11.0 \\
\hline & $(\mathrm{pCi} / \mathrm{L})$ & $(\mathrm{pCi} / \mathrm{L})$ & $(\mathrm{pCi} / \mathrm{kg})$ & $(\mathrm{pCi} / \mathrm{kg})$ \\
\hline C-14 (carcinogen) & 51 & 510 & 5100 & 51000 \\
\hline $\begin{array}{l}\text { Tc-99 } \\
\text { (carcinogen) }\end{array}$ & 35 & 350 & 3500 & 35000 \\
\hline I-129 (carcinogen) & 0.24 & 2.4 & 24 & 240 \\
\hline $\begin{array}{l}\mathrm{U}-238 \\
\text { (carcinogen) }\end{array}$ & 1.6 & 16.0 & 160 & 1600 \\
\hline
\end{tabular}

[By interpretation of: $W A C$ 173-303 \& WAC 173-340]

4.2.1.3.1-M1 C7 Radiation Protection. The "as low as reasonably achievable" (ALARA) guideline in WHC-CM-4-11 shall be implemented in the design of equipment, components, or assemblies, and in the planning of construction, installation, operation, maintenance, and decommissioning activities. Evaluations and cost-benefit analyses for determining that the radiation exposure levels are ALARA shall used the methodologies established in International Commission on Radiological Protection 37, "Cost-Benefit Analysis in the Optimization of Radiation Protection."

[WHC-CM-4-11] 
4.2.1.3.1-M1 C8 Tank Dome Loading. Total live loads on the tank dome are limited to a maximum of 50 tons for $20-\mathrm{ft}$ diameter tanks, and 100 tons for 75 - $\mathrm{ft}$ diameter tanks. These loads are assumed to occur on the soil covering the tank within a 10-ft radius of the tank center. Loads in excess of these shall be evaluated on a case-bycase basis and require approval by Single-Shell Tank Process Engineering and Tank Farm Operations. Loads imposed during barrier installation and operation, and other loads (e.g., waste retrieval equipment) shall be considered.

[OSD-T-151-00013, Revision D-1, Section 13.2.1, C(2)]

4.2.1.3.1-M1 C9 Temperature of Concrete Encasement. The temperature of the concrete encasement during barrier installation and operation is limited to a maximum of $250^{\circ} \mathrm{F}$ (HOLD). The rate of temperature change is limited to a maximum of $20^{\circ} \mathrm{F} /$ day (HOLD). Basis: Temperature limits are set to prevent structural damage to the tank which could cause the tank to leak.

[OSD-T-151-00013, Revision D-1, Section 13.2.1, E(1)]

\section{INTERFACE REQUIREMENTS}

See Section 4.0 for requirements allocated to the interfaces of this function. 


\section{FUNCTION ID NUMBER: 4.2.1.3.1-M1.1}

II. FUNCTION TITLE: Prevent New Leakage from SSTs

III. FUNCTION DEFINITION:

Prevent or minimize new SST leakage during waste retrieval activities per actions agreed upon with DOE-RL, Ecology, and EPA.

IV. ENABLING ASSUMPTIONS:

Decomposition of Function 4.2.1.3 will include the fifth-level function "Retrieve SST waste."

V. INTERFACES
A. INPUTS

Same as 4.2.1.3.1-M1

B. OUTPUTS

Same as 4.2.1.3.1-M1

VI. FUNCTION REQUIREMENTS

A. Performance Requirements

\section{Baseline}

Same as 4.2.1.3.1-M1

\section{Preferred Alternative - Close-coupled Barriers}

4.2.1.3.1-M1.1 PA1 Geometry. The close-coupled subsurface barrier shall be installed such that the barrier material forms a seal around the tank structural features that may leak during sluicing retrieval (Figure 2-2).

4.2.1.3.1-M1.1 PA2 Confinement. The installed close-coupled barrier shall provide confinement around the SST structure to a level that minimizes leakage into or past the barrier during the sluicing operation. This confinement capability must be maintained for a period of 30 years following installation.

4.2.1.3.1-M1.1 PA3 No Degradation to SST Structure. Installation and maintenance of the subsurface barrier shall not degrade the existing tank structure. 
B. Constraints

Same as 4.2.1.3.1-M1

VII. INTERFACE REQUIREMENTS

See Section 4.0 for requirements allocated to the interfaces of this function. 
I. FUNCTION ID NUMBER: 4.2.1.3.1-M1.2

II. FUNCTION TITLE: Confine Past Leaks from SSTs

III. FUNCTION DEFINITION:

Confine past SST leakage during waste retrieval activities per actions agreed upon with DOE-RL, Ecology, and EPA.

IV. ENABLING ASSUMPTIONS:

Decomposition of Function 4.2.1.3 will include the fifth-level function "Retrieve SST waste."

V. INTERFACES
A. INPUTS

Same as 4.2.1.3.1-M1

B. OUTPUTS

Same as 4.2.1.3.1-M1

VI. FUNCTION REQUIREMENTS

A. Performance Requirements

Same as 4.2.1.3.1-M1

B. Constraints

4.2.1.3.1-M1.2 C1 Migration of Leaks. For tank systems in interim status from which there has been a leak, the owner or operator must prevent further migration of the leak or spill to soils or surface water.

[40CFR265, Section 265.196(c)(1)]

4.2.1.3.1-M1.2 C2 Radionuclide Limits in Groundwater. The liquid effluents from DOE activities shall not cause private or public drinking water systems downstream of the facility discharge to exceed the drinking water radiological limits of 40 CFR 141 . These systems shall not cause persons consuming the water to receive an effective dose equivalent greater than $4 \mathrm{mrem} / \mathrm{yr}$. Combined ${ }^{226} \mathrm{Ra}$ and ${ }^{228} \mathrm{Ra}$ shall not exceed $5 \mathrm{E}-09 \mu \mathrm{Ci} / \mathrm{mL}$ and gross $\alpha$ activity (including ${ }^{226} \mathrm{Ra}$ but excluding radon and uranium) shall not exceed $1.5 \mathrm{E}-08 \mu \mathrm{Ci} / \mathrm{mL}$.

[DOE5400.5, Chapter II, 1d(3)] 
4.2.1.3.1-M1.2 C3 Migration of Leaks. Liquid discharges, even though uncontaminated, are prohibited in inactive release areas to prevent the further spread of radionuclides previously deposited, unless the discharge is part of an interim or final cleanup response.

[DOE5400.5, Chapter II, 3c(2)]

\section{INTERFACE REQUIREMENTS}

See Section 4.0 for requirements allocated to the interfaces of this function. 
I. FUNCTION ID NUMBER: 4.2.1.3.1-M1.3

II. FUNCTION TITLE: Remove Soil Contamination Resulting from SST Leakage

III. FUNCTION DEFINITION:

Remove soil contamination resulting from SST leakage during retrieval per actions agreed upon with DOE-RL, Ecology, and EPA.

IV. ENABLING ASSUMPTIONS:

Decomposition of Function 4.2.1.3 will include the fifth-level function "Retrieve SST waste."

V. INTERFACES

A. INPUTS

Same as 4.2.1.3.1-M1

B. OUTPUTS

Same as 4.2.1.3.1-M1

VI. FUNCTION REQUIREMENTS

Same as 4.2.1.3.1-M1

VII. INTERFACE REQUIREMENTS

See Section 4.0 for requirements allocated to the interfaces of this function. 
I. FUNCTION ID NUMBER: 4.2.1.3.1-M1.4

II. FUNCTION TITLE: Monitor Performance and Verify Compliance of Leakage Mitigation System

III. FUNCTION DEFINITION:

Monitor performance and verify compliance of leakage mitigation systems during retrieval to the extent needed and per actions agreed upon with DOE-RL, Ecology, and EPA.

IV. ENABLING ASSUMPTIONS:

Decomposition of Function 4.2.1.3 will include the fifth-level function "Retrieve SST waste."

V. INTERFACES

A. INPUTS

Same as 4.2.1.3.1-M1

B. OUTPUTS

Same as 4.2.1.3.1-M1

VI. FUNCTION REQUIREMENTS

A. Performance Requirements

Baseline

Same as 4.2.1.3.1-M1

Preferred Alternative - Close-coupled Barriers

4.2.1.3.1-M1.4 PA1 Leak Detection and Monitoring. Monitoring and leak detection capability shall be provided to verify acceptable performance of the installed close-coupled barrier.

B. Constraints 
4.2.1.3.1-M1.4 $\mathrm{C} 1$ Leak Detection. Monitoring and leak detection capability shall be incorporated in engineering systems to provide rapid identification of leaks and to assess system integrity.

[DOE5820.2A, Chapter I, 3b(3)(a,c)]

4.2.1.3.1-M1.4 C2 Defense Authorization Act, "Safety Measures for Waste Tanks at Hanford Nuclear Reservation," Section 3137 (also known as the Wyden Amendments). [Para a, Ensure that "...continuous monitoring to detect a release or excessive temperature or pressure..." is being carried out.]

[Public Law 101-510, Section 3137, (a)]

\section{INTERFACE REQUIREMENTS}

See Section 4.0 for requirements allocated to the interfaces of this function. 
I. FUNCTION ID NUMBER: $4.2 .3 .5 .2-\mathrm{M} 1$

II. FUNCTION TITLE: Mitigate SST Leakage to Achieve Closure Readiness

III. FUNCTION DEFINITION:

Mitigate soil contamination resulting from SST leakage to a level that will allow transfer to the Environmental Restoration Contractor for closure.

\section{ENABLING ASSUMPTIONS:}

Decomposition of Function 4.2.3.5 will include the fifth-level function "Remove Residual Inventories."

\section{INTERFACES}

\section{A. INPUTS}

\subsubsection{2-M1 I1 Single-Shell Tank Farms}

From: External

SST farms - including the tanks, ancillary systems (e.g., transfer lines, dry wells, groundwater monitoring wells, other above or belowground hardware), soil contamination plumes resulting from past or new leaks.

\subsubsection{2-M1 I2 SST Leakage Characterization Data}

From: 4.2.1.2

Information about SST leakage and soil contamination plumes.

\subsubsection{2-M1 I3 SST Waste Characterization Data}

From: 4.2 .1 .2

Information about the constituents of the waste in each tank.

\subsubsection{2-M1 I4 SST Integrity Data}

From: 4.2 .1 .1

Information about the structural integrity of SSTs, including maximum and minimum allowable loads and temperatures.

\subsubsection{2-B1 I5 Tank Farm Geological Data}

From: 4.2 .1 .2

Information about the tank farm geology, including soil properties, lithography, history, and hydrology. 


\section{B. OUTPUTS}

\subsubsection{2-M1 O1 Liquid Effluent}

To: 4 2.3.3

Liquid effluent streams resulting from SST leakage mitigation operations for treatment and disposal.

\subsubsection{2-M1 O2 Solid Waste}

To: 4.2 .3 .4

Solid waste generated from SST leakage mitigation system operations.

\subsubsection{2-M1 O3 Gaseous Effluent}

To: 4.2 .3 .2

Offgas streams resulting from SST leakage mitigation system operations for treatment and disposal.

4.2.3.5.2-M1 O4 Excess Equipment/Facilities

To: 4.2 .3 .5

SST leakage mitigation system components, once they are no longer needed in fulfillment of the TWRS mission.

\subsubsection{2-M1 O5 Reusable Materials}

To: 4.2 .3 .6

Materials economically suitable for reuse by TWRS or other programs.

\section{FUNCTION REQUIREMENTS}

\section{A. Performance Requirements}

\section{Baseline}

4.2.3.5.2-M1 P1 Mitigate leakage from SSTs in a manner that supports tank farm SST excess facility disposition activities and overall SST remediation objectives. The TWRS Program baseline approach is to take no action to mitigate SST leakage in support of excess facility disposition. In effect, this approach would utilize the tank farm vadose zone soil as a natural barrier to inhibit flow of any leaked contaminants to the environment. Subsurface barriers and other alternatives for mitigating SST leakage to support preparation of the SSTs for closure will be evaluated per TPA Milestone M-45-07A, (September 1994) "Complete Evaluation of Sub-surface Barrier Feasibility". 


\subsubsection{2-M1 P1 Issue 1}

Requirements for mitigation of SST leakage in order to meet the objective of "closure-ready SSTs" have not been defined (DOE/RL-92-60, Rev. 1, Table F4.2, Item 4.2 03 Issue 1).

\subsubsection{2-M1 P1 Issue 1 Required Analysis}

In conjunction with the Hanford Site Systems Engineering Functions and Requirements analysis, develop interface requirements for these items. A preliminary closure strategy and preliminary performance assessment for SSTs/DSTs may be required to establish interface requirements for the residual waste remaining in the tanks.

[DOE/RL-92-60, Table F4.2, Item 4.203 Issue 1]

\section{Preferred Alternative - Stand-off Subsurface Barriers with Soil Flushing}

4.2.3.5.2-M1 PA1 Install stand-off subsurface barriers with soil flushing removal and associated monitoring systems beneath SSTs that have leaked per interface requirements. Initial evaluations have identified the use of stand-off barriers with soil flushing as a potentially cost-effective method to prevent further migration and achieve removal of contaminants resulting from SST leakage and thereby minimize environmental impact.

\subsubsection{2-M1 PA1 Issue 1}

Requirements for mitigation of SST leakage in order to meet the objective of "closure-ready SSTs" have not been defined (DOE/RL-92-60, Rev. 1, Table F4.2, Item $4.2 \mathrm{O} 3$ Issue 1).

\subsubsection{2-M1 PA1 Issue 1 Required Analysis}

In conjunction with the Hanford Site Systems Engineering Functions and Requirements analysis, develop interface requirements for these items. A preliminary closure strategy and preliminary performance assessment for SSTs/DSTs may be required to establish interface requirements for the residual waste remaining in the tanks.

[DOE/RL-92-60, Table F4.2, Item 4.203 Issue 1]

\subsubsection{2-M1 PA1 Issue 2}

The viability of stand-off subsurface barriers with soil flushing as an alternative is dependant on the assumption that landfill closure of the tank farms will be permissible. If clean closure is ultimately required, then use of stand-off subsurface 
barriers to confine leakage and remove contamination is of limited value and would not be considered the preferred alternative.

\subsubsection{2-M1 PA1 Issue 2 Required Analysis}

The designation of the 200 Area as a limited use area has not been accepted by all stakeholder groups and may be subject to challenge.

$$
\text { [DOE/RL-92-60, Table F4.2, Item 4.2 P1 Issue 1] }
$$

In conjunction with the Hanford Site Systems Engineering Functions and Requirements analysis, develop interface requirements for these items. A preliminary closure strategy and preliminary performance assessment for SSTs/DSTs may be required to establish interface requirements for the residual waste remaining in the tanks.

[DOE/RL-92-60, Table F4.2, Item 4.2 O3 Issue 1]

4.2.3.5.2-M1 PA2 Installation, operation and maintenance of the subsurface barrier shall be non-controlling and shall support tank farm SST excess facilities disposition activities and overall SST remediation objectives.

\section{B. Constraints}

4.2.3.5.2-M1 C1 Waste Minimization. The quantity of waste being sent to storage shall be reduced. Basis: Significant volumes of radioactive solid waste may be generated as a result of barrier installation, operation, and (if needed) removal.

[DOE Order 5820.2A, Chapter I, 3b(7)(a)]

4.2.3.5.2-M1 C2 M-45-07 (September 1997) Complete Evaluation and Demonstration Testing of Sub-scale Barriers

DOE will assess the risk to the environment due to tank waste remediation. DOE with concurrence from Ecology and EPA will evaluate barrier technology as a means to minimize those risks and vendor capabilities to deploy and test barriers in Hanford soils. Retrieval of waste from tank 241-C-106 will proceed without a barrier.

M-45-07A (September 1994) Complete Evaluation of Sub-surface Barrier Feasibility

Complete a feasibility study of barriers to accomplish the following:

1) Estimate the potential environmental impact of waste storage and retrieval activities without the application of barriers.

2) Establish functional requirements of barriers to minimize the impact associated with the waste storage and retrieval activities. 
3) Evaluate the application of existing sub-surface barrier technologies to meet functional requirements of barriers and the potential reduction in environmental impacts from the application of barriers to SST waste storage and retrieval activities.

\section{M-45-07B (January 1995) Reach Decision on Whether to Proceed with Demonstration}

Based on the results of the sub-surface barrier feasibility study, Ecology, EPA, and DOE will make a decision on whether to proceed with a sub-scale demonstration. If the decision is negative, then interim milestone $\mathrm{M}-45-07$ will be considered complete.

\section{M-45-07-T1 (March 1995) Establish Performance Criteria and Test Specifications}

Ecology, EPA, and DOE establish and reach agreement on performance criteria and test specifications to be used for the sub-Scale demonstration of sub-surface barrier technologies.

M-45-07-T2 (October 1995) Initiate Demonstration Testing of Selected Sub-Surface Barrier Technologies

Sub-scale testing of one or more sub-surface barrier technologies will be initiated at a Hanford test site. Documentation will be completed prior to testing which will incorporate performance criteria and test specifications. Initiation of demonstration is defined as completion of construction and initiation of test procedures.

M-45-07-T3 (March 1997) Complete Evaluation of Sub-Surface Barrier Demonstration Test Results

Test data and related information will be provided to Ecology, EPA, and DOE as it becomes available during testing. Sub-surface barrier technologies will be evaluated against the performance criteria and test specifications.

M-45-07-T4 (June 1997) Reach Decision on Whether to Proceed with Sub-Surface Barrier Program

Ecology, EPA, and DOE will make a decision on whether to proceed with installation of a full-scale sub-surface barrier to support SST retrieval under milestone M-45-07. If the decision is negative, then milestone $\mathrm{M}-45-07$ will be considered complete.

M-45-07C (September 1997) Establish New Milestones for Sub-Surface Barrier Implementation

Ecology, EPA, and DOE will negotiate and reach agreement on new milestones to support milestone M-45-07 and a program to install sub-surface barriers in SST farms or individual tanks to support SST retrieval schedules under M-45-00. New 
milestones will include completion of construction of construction of a full-scale subsurface barrier in a tank farm, in conjunction with the installation of the retrieval systems pursuant to M-45-04-T3 (complete construction for the initial SST retrieval systems).

[TPA Change Control Form $M-45-00]$

4.2.3.5.2-M1 C3 M-45-06 (September 2024) Complete Closure on All Single-Shell Tank Farms. The single-shell tank closure work plan will be prepared describing the work integration process for single-shell tank closures and status of work and integration process. Known issues will be identified and an explanation will be given on how these issues are being addressed. This work plan will be used as a roadmap for closure of the single-shell tanks. Because of the uncertainties in the closure process, the work plan will evolve as these uncertainties are resolved and eventually it will become the SST closure/post-closure plan(s) issued for ecology's approval under subsequent TPA interim milestones. Major work areas covered in the work plan will include waste retrieval, operable units characterization, technologies development to support closure, regulatory pathway and strategy for achieving closure.

M-45-06-T01 (November 2004) Submit Tank Closure/Post-Closure Plan for Selected Closure Demonstration Operable Unit or Tank Farm to Ecology for Approval.

M-45-06-T02 (September 2006) Ecology Will Issue Final Closure/Post Closure Plan For Selected Closure Demonstration Operable Unit or Tank Farm.

M-45-06-T03 (March 2012) Initiate Closure Actions on an Operable Unit or Tank Farm Basis. Closure Shall Follow Completion of The Retrieval Actions Under Proposed Milestone.

M-45-06-T04 (March 2014) Complete closure actions on one operable unit or tank farm.

[TPA Change Control Form M-45-06]

4.2.3.5.2-M1 C4 Well Drilling. Monitoring wells and other bore holes shall be appropriately sealed after use so as to not provide a pathway for contamination to the groundwater. Basis: Barrier installation will likely involve some type of drilling (e.g., vertical, angle, or horizontal bore holes).

[WAC 173-160]

4.2.3.5.2-M1 C5 (2) Closure performance standard. The owner or operator must close the facility in a manner that: (a)(i) Minimizes the need for further maintenance; (ii) Controls, minimizes or eliminates to the extent necessary to protect human health and the environment, postclosure escape of dangerous waste, dangerous constituents, leachate, contaminated run-off, or dangerous waste decomposition products to the ground, surface water, ground water, or the atmosphere; and (iii) Returns the land to 
the appearance and use of surrounding land areas to the degree possible given the nature of the previous dangerous waste activity.

[WAC 173-303-610(2)(a)]

4.2.3.5.2-M1 C6 (8) Closure and post-closure care.

(a) At closure of a tank system, the owner or operator must remove or decontaminate all waste residues, contaminated containment system components (liners, etc.), contaminated soils, and structures and equipment contaminated with waste, and manage them as dangerous waste, unless WAC 173-303-070 (2)(a) applies. The closure plan, closure activities, cost estimates for closure, and financial responsibility for tank systems must meet all of the requirements specified in WAC 173-303-610 and 173-303-620.

(b) If the owner or operator demonstrates that not all contaminated soils can be practicably removed or decontaminated as required in (a) of this subsection, then the owner or operator must close the tank system and perform post-closure care in accordance with the closure and post-closure care requirements that apply to landfills (see WAC 173-303-665(6)). In addition, for the purposes of closure, post-closure, and financial responsibility, such a tank system is then considered to be a landfill, and the owner or operator must meet all of the requirements for landfills specified in WAC 173-303-610 and 173-303-620.

(c) If an owner or operator has a tank system that does not have secondary containment that meets the requirements of subsection (4)(b) through (f) of this section and is not exempt from the secondary containment requirements in accordance with subsection $(4)(\mathrm{g})$ of this subsection.

(i) The closure plan for the tank system must include both a plan for complying with (a) of this subsection and a contingent plan for complying with (b) of this subsection.

(ii) A contingent post-closure plan for complying with (b) of this subsection must be prepared and submitted as part of the permit application.

(iii) The cost estimates calculated for closure and post-closure care must reflect the costs of complying with the contingent closure plan and the contingent closure plan and the contingent post-closure plan, if those costs are greater than the costs of complying with the closure plan prepared for the expected closure under (a) of this subsection.

(iv) Financial assurance must be based on the cost estimates in (c)(iii) of this subsection.

(v) For the purposes of the contingent closure and post-closure plans, such a tank system is considered to be a landfill, and the contingent plans must meet all of the closure, post-closure and financial responsibility requirements for landfills under this chapter (WAC 173-303-610 and173-303-620).

[WAC 173-303-640(8)] 
4.2.3.5.2-M1 C7 Groundwater Protection. Groundwater protection standards applicable to the Hanford single and double shell radioactive waste storage tanks can be divided into two categories: those applicable during tank operations and the closure period, and those that must ultimately be met to achieve closure.

Under Chaper 173-303 of Washington Administrative Code (WAC), concentrations of dangereous waste constituents regulated by Chapter 173-303 WAC in the groundwater beneath an active treatment, storage or disposal (TSD) facility, or a TSD facility undergoing closure, must not exceed local background levels or, for the toxicity characteristic (TC) metals and pesticides, a concentration $1 / 100$ the toxicity characteristic concentration for designation as a dangerous waste listed in WAC 173303-090 (these actual concentrations are tabulated in WAC 173-303-645). These limits could technically apply during the postclosure period for any unit where a clean closure is not achieved; however, it is more likely that any postclosure limits will be established consistent with the overall strategy for groundwater protection and remediation at the Hanford Site, as described below.

Due to the long travel times for contaminants to reach the aquifers underlying the Hanford Site, it is unlikely that a release from a tank TSD unit during the closure period (e.g., while wastes are being removed from the tank) would reach the water table and cause these "operational" groundwater limits to be exceeded. Furthermore, groundwater contamination at the Hanford Site is an extremely complex problem, with interactions between numerous contributing operable units that are undergoing remediation and closure under both the CERCLA and RCRA programs. It is likely that the Hanford Site will adopt a strategy of remediating all groundwater contamination to levels consistent with the goals of the CERCLA and RCRA programs, as well as related NRC guidance. Both Chapter 173-303 WAC and the CERCLA ARARs process are likely to establish cleanup/closure levels based on the health-risk based concentrations established under Chapter 173-340 WAC, the Model Toxics Control Act (MTCA) implementing regulation. The MTCA Method B cleanup standards have been incorporated into Chapter 173-303 WAC by reference as the appropriate clean closure and corrective action standards for RCRA TSD units in Washington State. The MTCA standards are also explicitly called out as ARARs for the Hanford Site under the Tri Party Agreement. Therefore, it is likely that the ultimate groundwater protection standard established for the tank waste remediation program will be based on a demonstration that releases will not cause the MTCA standards to be exceeded at any time.

Under MTCA, groundwater cleanup levels are set so as to ensure that the total toxic constituents do not exceed a Health Index (HI) of 1 , and that carcinogenic substance concentrations do not cause a carcinogenic risk greater than $10^{-6}$ (Method B) or $10^{-5}$ (Method C). Soil cleanup standards protective of groundwater are set at a level 100 times the groundwater protection standard as a default; this level may be adjusted through a site-specific evaluation of contaminant fate and transport. These health-risk 
based levels are consistent with the range of uniform cleanup standards under consideration by the NRC and EPA for sites containing radioactive contaminants

The following table provides MTCA Method B and C standards for the eight compounds identified in ongoing evaluations as the risk drivers for waste tank remediation, due to their relatively high mobility in the Hanford Site environment. These concentrations assume that the only exposure pathway is through ingestion of contaminated groundwater; other exposure pathways (e.g., inhalation of contaminated groundwater through showering) are not considered. In instances where the maximum contaminant level (MCL) is lower than the calculated MTCA Method B and $\mathrm{C}$ levels, the MCL has been used. The calculations assume a 30 year exposure period over which $2 \mathrm{~L}$ /day of contaminated groundwater is ingested, and a 75 year lifetime, and an average body weight of $16 \mathrm{~kg}$ (non-carcinogens) or $70 \mathrm{~kg}$ (carcinogens). These standards also assume that each constituent is the only hazardous material present; for mixtures of constituents, a weighted contribution calculation must be performed (e.g., the sum of the concentrations for each non-carcinogenic constituent divided by the values for each of these constituents listed below must be less than 1). 
Groundwater Protection Standards for Hanford Site Tank Waste Remediation

\begin{tabular}{|l|c|c|c|c|}
\hline \multicolumn{1}{|c|}{ Contaminant } & $\begin{array}{c}\text { MTCA } \\
\text { Method B } \\
\text { for } \\
\text { Groundwater } \\
(\mathrm{mg} / \mathrm{L})\end{array}$ & $\begin{array}{c}\text { MTCA } \\
\text { Method C } \\
\text { for } \\
\text { Groundwater } \\
(\mathrm{mg} / \mathrm{L})\end{array}$ & $\begin{array}{c}\text { MTCA Soils } \\
\text { (based on } \\
\text { Method B } \\
\text { Groundwater) } \\
\text { (mg/kg) }\end{array}$ & $\begin{array}{c}\text { MTCA Soils } \\
\text { (based on } \\
\text { Method C } \\
\text { Groundwater) } \\
(\mathrm{mg} / \mathrm{kg})\end{array}$ \\
\hline $\begin{array}{l}\text { EDTA (non- } \\
\text { carcinogen) }\end{array}$ & 0.021 & 0.046 & 2.1 & 4.6 \\
\hline $\begin{array}{l}\text { Nitrate (non- } \\
\text { carcinogen) }\end{array}$ & $10^{*}$ & --- & $1000^{*}$ & --- \\
\hline $\begin{array}{l}\text { Nitrite (non- } \\
\text { carcinogen) }\end{array}$ & $1 *$ & ---- & $100^{*}$ & $\cdots$ \\
\hline TBP (carcinogen) & 0.011 & 0.11 & 1.1 & 11.0 \\
\hline & $(\mathrm{pCi} / \mathrm{L})$ & $(\mathrm{pCi} / \mathrm{L})$ & $(\mathrm{pCi} / \mathrm{kg})$ & $(\mathrm{pCi} / \mathrm{kg})$ \\
\hline C-14 (carcinogen) & 51 & 510 & 5100 & 51000 \\
\hline $\begin{array}{l}\text { Tc-99 } \\
\text { (carcinogen) }\end{array}$ & 35 & 350 & 3500 & 35000 \\
\hline I-129 (carcinogen) & 0.24 & 2.4 & 24 & 240 \\
\hline $\begin{array}{l}\text { U-238 } \\
\text { (carcinogen) }\end{array}$ & 1.6 & 16.0 & 160 & 1600 \\
\hline
\end{tabular}

[By interpretation of:

WAC 173-303 \& WAC 173-340]

4.2.3.5.2-M1 C8 Radiation Protection. The "as low as reasonably achievable" (ALARA) guideline in WHC-CM-4-11 shall be implemented in the design of equipment, components, or assemblies, and in the planning of construction, installation, operation, maintenance, and decommissioning activities. Evaluations and cost-benefit analyses for determining that the radiation exposure levels are ALARA shall used the methodologies established in International Commission on Radiological Protection 37, "Cost-Benefit Analysis in the Optimization of Radiation Protection."

[WHC-CM-4-11]

4.2.3.5.2-M1 C9 Tank Dome Loading. Total live loads on the tank dome are limited to a maximum of 50 tons for $20-\mathrm{ft}$ diameter tanks, and 100 tons for $75-\mathrm{ft}$ diameter tanks. These loads are assumed to occur on the soil covering the tank within a $10-\mathrm{ft}$ radius of the tank center. Loads in excess of these shall be evaluated on a case-bycase basis and require approval by Single-Shell Tank Process Engineering and Tank 
Farm Operations. Loads imposed during barrier installation and operation, and other loads (e.g., waste retrieval equipment) shall be considered.

[OSD-T-151-00013, Revision D-1, Section 13.2.1, C(2)]

4.2.3.5.2-M1 C10 Temperature of Concrete Encasement. The temperature of the concrete encasement during barrier installation and operation is limited to a maximum of $250^{\circ} \mathrm{F}$ (HOLD). The rate of temperature change is limited to a maximum of $20^{\circ} \mathrm{F} /$ day (HOLD). Basis: Temperature limits are set to prevent structural damage to the tank which could cause the tank to leak.

[OSD-T-151-00013, Revision D-1, Section 13.2.1, E(1)]

\section{INTERFACE REQUIREMENTS}

See Section 4.0 for requirements allocated to the interfaces of this function. 


\section{FUNCTION ID NUMBER: 4.2.3.5.2-M1.1}

II. FUNCTION TITLE: Confine Past Leaks from SSTs

\section{FUNCTION DEFINITION:}

Confine past SST leakage per actions agreed upon with DOE-RL, Ecology, and EPA.

\section{ENABLING ASSUMPTIONS:}

Decomposition of Function 4.2.3.5 will include the fifth-level function "Remove Residual Inventories."

\section{INTERFACES}

\section{A. INPUTS}

Same as 4.2.3.5.2-M1

B. OUTPUTS

Same as 4.2.3.5.2-M1

VI. FUNCTION REQUIREMENTS

A. Performance Requirements

Baseline

Same as 4.2.3.5.2-M1

Preferred Alternative - Stand-off Subsurface Barriers with Soil Flushing

4.2.3.5.2-M1.1 PA1 Geometry. The stand-off subsurface barrier shall be installed such that the barrier material forms a confining basin around the tank or tanks in a vee or box configuration (Figures 2-3 and 2-4).

4.2.3.5.2-M1.1 PA2 Confinement. The installed stand-off barrier shall provide confinement around the tank or tanks to a level that minimizes leakage into or past the barrier during a 30 -year operating period following installation. In addition, the barrier shall be capable of confining any design basis events of the soil flushing system.

4.2.3.5.2-M1.1 PA3 No Degradation to SST Structure. Installation and maintenance of the subsurface barrier shall not degrade the existing tank structure. 


\section{B. Constraints}

4.2.3.5.2-M1.1 C1 Migration of Leaks. For tank systems in interim status from which there has been a leak, the owner or operator must prevent further migration of the leak or spill to soils or surface water.

[40CFR265, Section 265.196(c)(1)]

4.2.3.5.2-M1.1 C2 Radionuclide Limits in Groundwater. The liquid effluents from DOE activities shall not cause private or public drinking water systems downstream of the facility discharge to exceed the drinking water radiological limits of 40 CFR 141 . These systems shall not cause persons consuming the water to receive an effective dose equivalent greater than $4 \mathrm{mrem} / \mathrm{yr}$. Combined ${ }^{226} \mathrm{Ra}$ and ${ }^{228} \mathrm{Ra}$ shall not exceed $5 \mathrm{E}-09 \mu \mathrm{Ci} / \mathrm{mL}$ and gross $\alpha$ activity (including ${ }^{226} \mathrm{Ra}$ but excluding radon and uranium) shall not exceed $1.5 \mathrm{E}-08 \mu \mathrm{Ci} / \mathrm{mL}$.

[DOE5400.5, Chapter II, Id(3)]

4.2.3.5.2-M1.1 C3 Migration of Leaks. Liquid discharges, even though uncontaminated, are prohibited in inactive release areas to prevent the further spread of radionuclides previously deposited, unless the discharge is part of an interim or final cleanup response.

[DOE5400.5, Chapter II, 3c(2)]

\section{INTERFACE REQUIREMENTS}

See Section 4.0 for requirements allocated to the interfaces of this function. 
I. FUNCTION ID NUMBER: 4 -2.3.5.2-M1.2

II. FUNCTION TITLE: Remove Soil Contamination Resulting from SST Leakage

III. FUNCTION DEFINITION:

Remove soil contamination resulting from SST leakage per actions agreed upon with DOE-RL, Ecology, and EPA.

IV. ENABLING ASSUMPTIONS:

Decomposition of Function 4.2.3.5 will include the fifth-level function "Remove Residual Inventories."

V. INTERFACES
A. INPUTS

Same as 4.2.3.5.2-M1

B. OUTPUTS

Same as 4.2.3.5.2-M1

VI. FUNCTION REQUIREMENTS

A. Performance Requirements

Baseline

Same as 4.2.3.5.2-M1

Preferred Alternative - Stand-off Subsurface Barriers with Soil Flushing

4.2.3.5.2-M1.4 PA1 Contaminant Removal. Remove contaminants utilizing soil flushing per interface requirements.

B. Constraints

Same as 4.2.3.5.2-M1

VII. INTERFACE REQUIREMENTS

See Section 4.0 for requirements allocated to the interfaces of this function. 
I. FUNCTION ID NUMBER: 4.2.3.5.2-M1.3

II. FUNCTION TITLE: Monitor Performance and Verify Compliance of Leakage Mitigation System

III. FUNCTION DEFINITION:

Monitor performance and verify compliance of leakage mitigation system to the extent needed and per actions agreed upon with DOE-RL, Ecology, and EPA.

IV. ENABLING ASSUMPTIONS:

Decomposition of Function 4.2.3.5 will include the fifth-level function "Remove Residual Inventories."

V. INTERFACES

A. INPUTS

Same as 4.2.3.5.2-M1

B. OUTPUTS

Same as 4.2.3.5.2-M1

VI. FUNCTION REQUIREMENTS

A. Performance Requirements

Baseline

Same as 4.2.3.5.2-M1

Preferred Alternative - Stand-off Subsurface Barriers with Soil Flushing

4.2.3.5.2-M1.4 PA1 Leak Detection and Monitoring. Monitoring and leak detection capability shall be provided to verify acceptable performance of the installed stand-off subsurface barrier and soil flushing system.

B. Constraints

4.2.3.5.2-M1.4 C1 Leak Detection. Monitoring and leak detection capability shall be incorporated in engineering systems to provide rapid identification of leaks and to assess system integrity.

[DOE5820.2A, Chapter I, 3b(3) $(a, c)]$ 
4.2.3.5.2-M1.4 C1 Defense Authorization Act, "Safety Measures for Waste Tanks at Hanford Nuclear Reservation," Section 3137 (also known as the Wyden Amendments). [Para a, Ensure that "...continuous monitoring to detect a release or excessive temperature or pressure..." is being carried out.]

[Public Law 101-510, Section 3137, (a)]

\section{INTERFACE REQUIREMENTS}

See Section 4.0 for requirements allocated to the interfaces of this function. 
Figure 2-2. Close-Coupled Subsurface Barrier Concept.

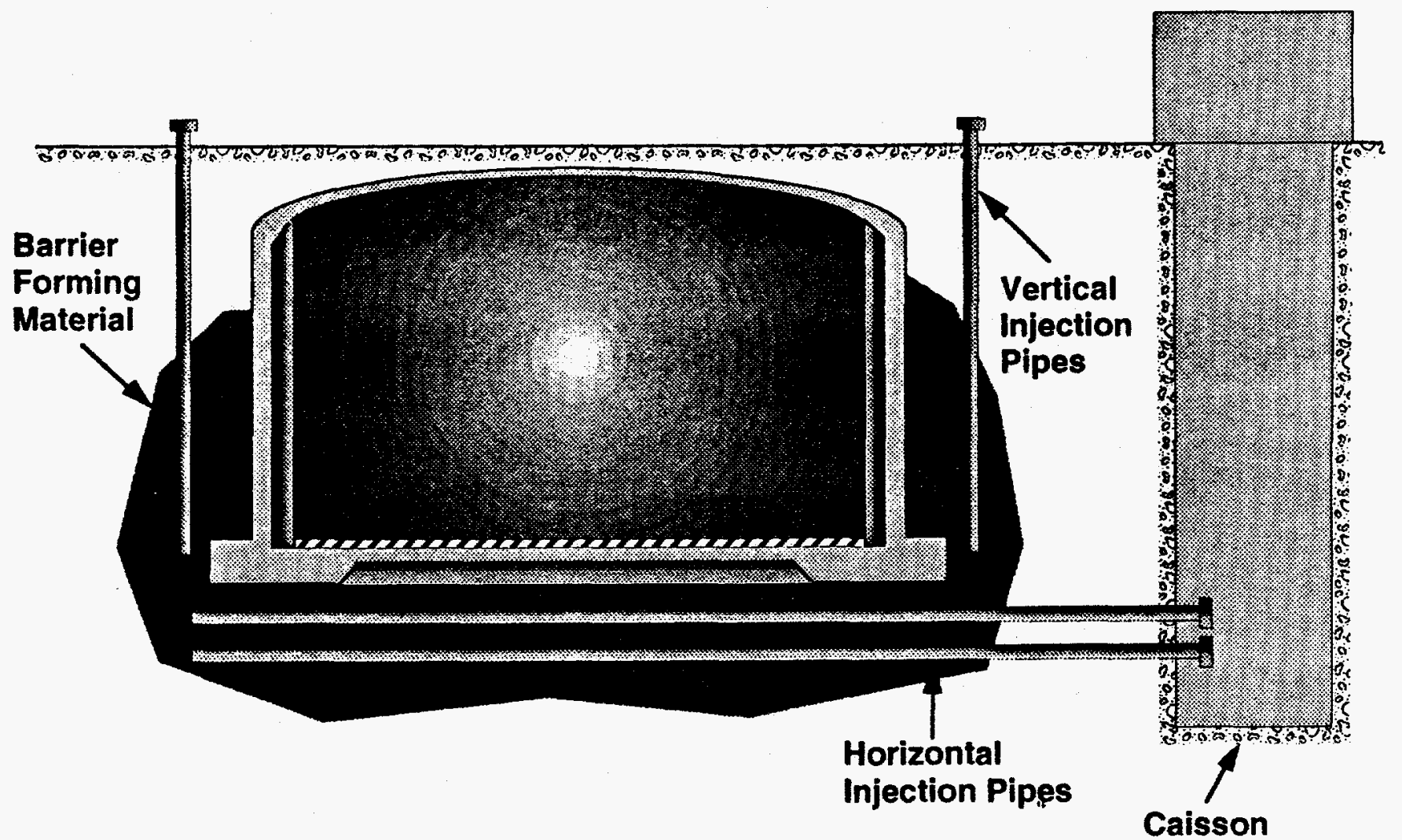

39404150.23 


\section{WHC-SD-WM-FRD-019 REV. 0}

Figure 2-3. Stand-Off (Vee) Subsurface Barrier Concept.

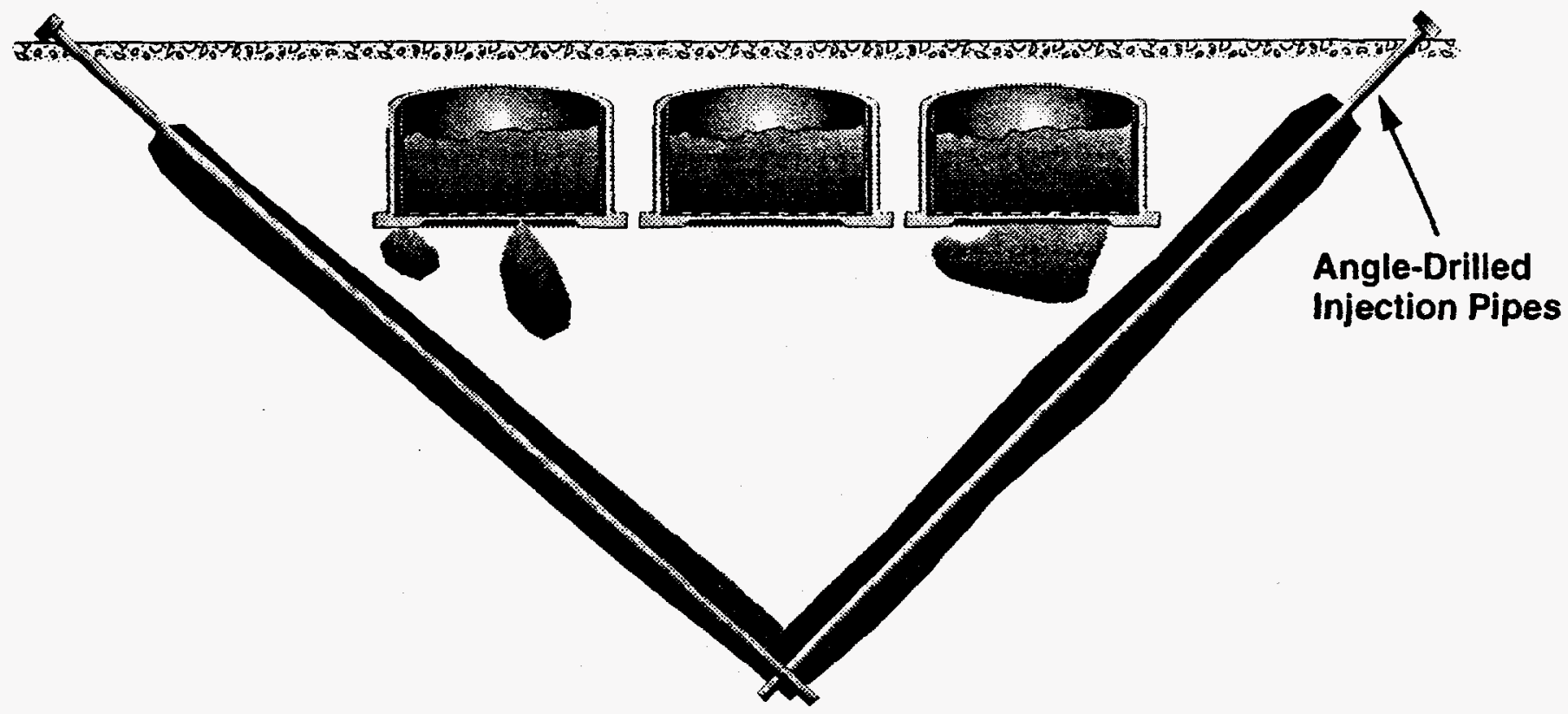

39404150.25 
Figure 2-4. Stand-Off (Box) Subsurface Barrier Concept.

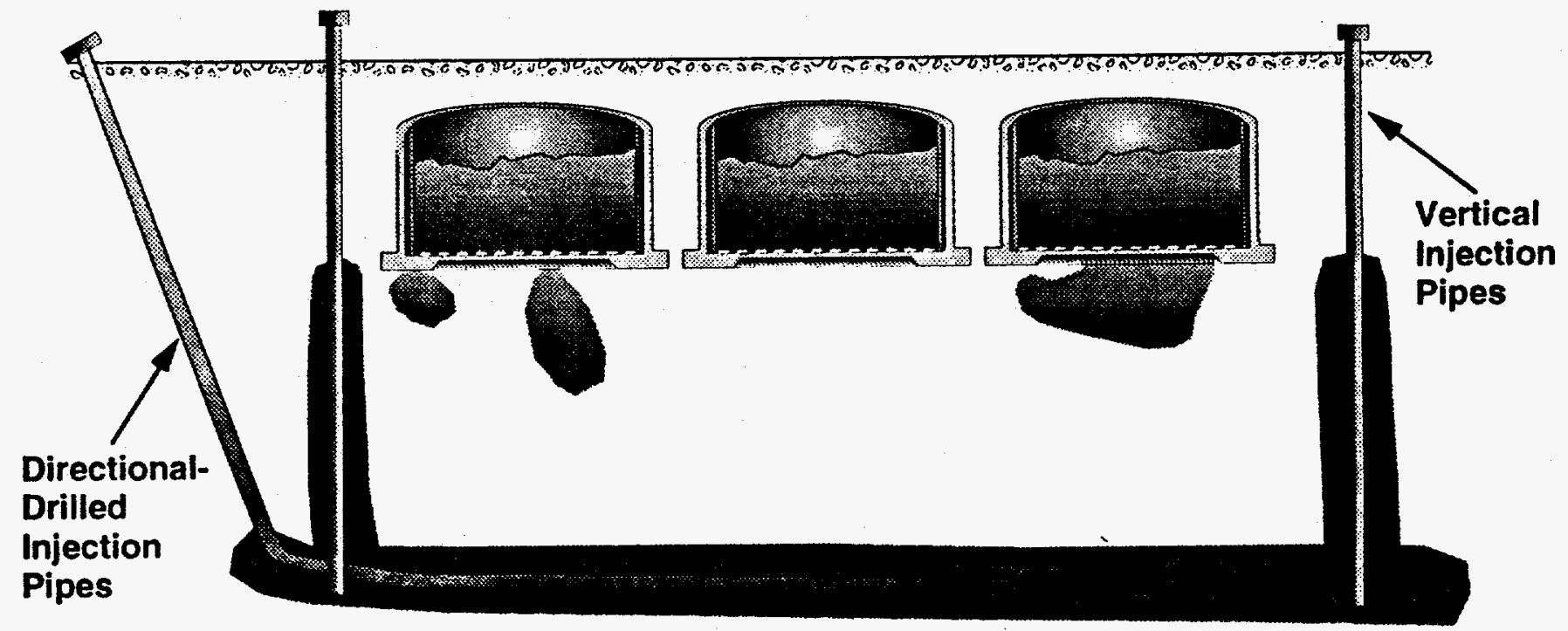

39404150.24 
WHC-SD-WM-FRD-019 REV. 0

This page intentionally left blank. 


\subsection{ARCHITECTURE}

Architecture descriptions were developed for each of the SST Leakage Mitigation functions and are presented in this section. A number of the functions have invoked a baseline architecture and a set of alternatives with the final selection pending per Hanford Federal Facility Agreement and Consent Order (TPA) Milestone M-45-07. The architectures were decomposed in a manner consistent with the functions and requirements. The architectures described herein were decomposed from TWRS fourth-level architectures as identified in DOE/RL-92-60 Rev. 1, Tank Waste Remediation System Functions and Requirements and three assumed fifth-level architectures. The primary sixth-level architectures establish the general aspects of the SST Leakage Mitigation systems. The seventh-level subarchitectures were established to define the baseline and alternative methods in greater detail.

The architecture descriptions were developed to facilitate better definition of potential system design concepts. As the concepts are further evaluated and decisions are made regarding implementation, the architecture descriptions will be revised as appropriate.

\subsection{ARCHITECTURE HIERARCHY}

Each architecture identified for SST Leakage Mitigation is given a number of the format A4.2.i.j.k-Mx or -Mx.y. The first part of the number, A4.2.i.j.k, is the number of the assumed TWRS fifth-level architecture from which the project-level architecture was decomposed. The "-M" indicates that it is a architecture allocated to SST Leakage Mitigation. The " $x$ " or "x.y" completes the unique number within each "4.2.i.j.k" group. For example, A4.2.1.1.2-M1 indicates an architecture decomposed from TWRS architecture A4.2.1.1.2 and allocated to the SST Leakage Mitigation system; and A4.2.1.1.2-M1.1 indicates a sub-architecture of A4.2.1.1.2-M1.

Figure 3-1 illustrates the hierarchy of the SST Leakage Mitigation architectures, as decomposed from the TWRS fourth-level architectures. Figure A-2 in Appendix A of this document shows the hierarchy of the TWRS architectures to the fourth level.

\subsection{ARCHITECTURE DESCRIPTION SHEETS}

An Architecture Description Sheet is provided for each of the architectures identified for SST Leakage Mitigation. The Architecture Description Sheets provide the architecture definitions, alternatives considered, rationale for selection, and other data. The sheets were prepared according to the format used in DOE/RL-92-60, as shown in Appendix A. 
WHC-SD-WM-FRD-019 REV. 0

Figure 3-1. SST Leakage Mitigation Architecture Hierarchy.

[Reserved] 
I. ARCHITECTURE ID NUMBER: A4.2.1.1.2-M1

II. ARCHITECTURE TITLE: SST Leakage Mitigation System

III. ARCHITECTURE DEFINITION:

The SST tank farm near-field and vadose zone soil will be utilized to inhibit the migration of any tank leakage plumes to the environment. This basically represents $a$ no action scenario. Subsurface barriers and other options for mitigating SST leakage that may result from storage activities will be evaluated per TPA Milestone M-45-07, (September 1994) "Complete Evaluation of Sub-surface Barrier Feasibility".

\section{ALTERNATIVES CONSIDERED:}

A number of alternative architectures were considered for application to this function:

- No action involves use of the near-field and vadose zone soil as a natural barrier between the tank-farms and the environment. This is the current architecture unless the evaluations and decision process per TPA Milestone M-45-07 lead to selection of another.

- $\quad$ Close-coupled subsurface barriers were considered as an alternative for "Prevention and Minimization of New Leakage"; see A4.2.1.1.2-M1.1.

- Stand-off subsurface barriers were considered as an alternate for "Confinement of Past Leaks"; see A4.2.1.1.2-M1.2.

- Soil Flushing and Excavation were considered as alternates for "Removal of Soil Contamination"; see A4.2.1.1.2-M1.3.

- $\quad$ Subsurface leak detection was considered as an alternate for "Monitor Performance and Verify Integrity"; see A4.2.1.1.2-M1.4.

\section{RATIONALE FOR SELECTION:}

The current TWRS program baseline does not include any action to mitigate the threat of leakage from SSTs during storage activities. During storage, there is little threat of further leakage because the tanks will remain in a mostly undisturbed state. Leakage potential is being reduced by interim stabilization, which removes pumpable liquids from the SSTs, thereby reducing the potential driving head for new leakage (TPA Milestone M-41-00 (September 2000) Complete SST interim stabilization).

Soil contamination resulting from past leaks will continue to migrate slowly. However, the transport time to the groundwater is approximately 200 years or longer depending on the hydrogeologic conditions of the site. Accordingly, a more effective 
overall strategy for confinement and removal (if needed) would be to take action on contamination from past leaks following completion of retrieval activities on a tank farm by tank farm basis. This would eliminate the need for repetitive removal operations in the event new leakage occurred during retrieval; see Section 2.2, Function 4.2.3.5.2-M1.

An architecture for "Monitor Performance and Verify Integrity" is invoked only if a subsurface barrier concept is utilized; therefore, no architecture is needed.

\section{ENABLING ASSUMPTIONS:}

Decomposition of architecture 4.2.1.1 will include the fifth-level architecture "Store SST waste."

\section{REQUIRED ANALYSES:}

Evaluation as per TPA Milestone M-45-07A:

"M-45-07A (September 1994) Complete Evaluation of Sub-surface Barrier Feasibility

Complete a feasibility study of barriers to accomplish the following:

1) Estimate the potential environmental impact of waste storage and retrieval activities without the application of barriers.

2) Establish functional requirements of barriers to minimize the impact associated with the waste storage and retrieval activities.

3) Evaluate the application of existing sub-surface barrier technologies to meet functional requirements of barriers and the potential reduction in environmental impacts from the application of barriers to SST waste storage and retrieval activities."

VII. REQUIREMENTS SATISFIED:
A. Estimated System Performance:
B. Performance Requirements: 


\section{ARCHITECTURE ID NUMBER: A4.2.1.1.2-M1.1}

II. ARCHITECTURE TITLE: SST Leakage Prevention

\section{ARCHITECTURE DEFINITION:}

No action will be taken to prevent SST leakage during waste storage activities other than interim stabilization (TPA Milestone M-41-00).

\section{ALTERNATIVES CONSIDERED:}

- No action involves use of the near-field and vadose zone soil as a natural barrier between the tank-farms and the environment. This is the current architecture unless the evaluations and decision process per TPA Milestone M-45-07 lead to selection of another.

- Close-coupled subsurface barriers involves the installation of barrier material into the soil immediately surrounding the tank structure forming a seal (Figure 2-2). This barrier would prevent new leakage and thereby prevent new soil contamination.

\section{RATIONALE FOR SELECTION:}

Same as A4.2.1.1.2-M1.

VI. ENABLING ASSUMPTIONS:

Same as A4.2.1.1.2-M1.

VII. REQUIRED ANALYSES:

Same as A4.2.1.1.2-M1.

VIII. REQUIREMENTS SATISFIED:
A. Estimated System Performance:
B. Performance Requirements: 


\section{ARCHITECTURE ID NUMBER: A4.2.1.1.2-M1.2}

II. ARCHITECTURE TITLE: SST Leakage Confinement System

III. ARCHITECTURE DEFINITION:

No action will be taken to confine soil contamination resulting from previous SST leakage during waste storage activities.

\section{ALTERNATIVES CONSIDERED:}

- No action involves use of the near-field and vadose zone soil as a natural barrier between the tank-farms and the environment. This is the current architecture unless the evaluations and decision process per TPA Milestone M-45-07 lead to selection of another.

- $\quad$ Stand-off subsurface barriers involves installation of a layer of barrier material surrounding a tank or tank farm in a geometry that leaves a layer of soil beneath and around the tank structure(s) Figures (2-3 and 2-4). The barrier would be installed and maintained while soil flushing was used to remove contamination - see A4.2.1.1.2-M1.3.

\section{RATIONALE FOR SELECTION:}

Same as A4.2.1.1.2-M1.

VI. ENABLING ASSUMPTIONS:

Same as A4.2.1.1.2-M1.

VII. REQUIRED ANALYSES:

Same as A4.2.1.1.2-M1.

VIII. REQUIREMENTS SATISFIED:
A. Estimated System Performance:
B. Performance Requirements: 


\section{ARCHITECTURE ID NUMBER: A4.2.1.1.2-M1.3}

II. ARCHITECTURE TITLE: Soil Contamination Removal System

\section{ARCHITECTURE DEFINITION:}

No action will be taken to remove soil contamination resulting from SST leakage during storage activities.

\section{ALTERNATIVES CONSIDERED:}

- No action involves use of the near-field and vadose zone soil as a natural barrier between the tank-farms and the environment. This is the current architecture unless the evaluations and decision process per TPA Milestone M-45-07 lead to selection of another.

- Soil Flushing involves installation of injection pipes in an upper layer and collection pipes in a lower layer. Flushing liquid is introduced in the injection pipes and leachate is collected at the collection pipes. Soil flushing would be utilized either with or without a subsurface (stand-off) barrier. The barrier would prevent the potential further spread of contamination due to the driving forces of the flushing liquid.

- Excavation involves removing the soil that contains contamination and replacing it with clean soil. The contaminated soil is transferred to a treatment storage and disposal facility for treatment.

V. RATIONALE FOR SELECTION:

Same as A4.2.1.1.2-M1.

VI. ENABLING ASSUMPTIONS:

Same as A4.2.1.1.2-M1.

VII. REQUIRED ANALYSES:

Same as A4.2.1.1.2-M1.

VII. REQUIREMENTS SATISFIED:
A. Estimated System Performance:
B. Performance Requirements: 
I. ARCHITECTURE ID NUMBER: A4.2.1.1.2-M1.4

II. ARCHITECTURE TITLE: Performance Monitoring and Compliance Verification System

\section{ARCHITECTURE DEFINITION:}

No action will be taken to monitor performance and verify compliance of leakage mitigation systems during storage activities, because no physical systems will be installed.

\section{ALTERNATIVES CONSIDERED:}

- $\quad$ No action involves use of the near-field and vadose zone soil as a natural barrier between the tank-farms and the environment. This is the current architecture unless the evaluations and decision process per TPA Milestone M-45-07 lead to selection of another. Because no subsurface barriers are installed in this case, no monitoring or verification of barrier performance is needed.

- Subsurface leak detection involves installation of leak detection instrumentation near or around (belowground) subsurface barrier structures to detect any leakage that may escape the barrier structure. This architecture is needed only if a barrier is used.

\section{RATIONALE FOR SELECTION:}

Same as A4.2.1.1.2-M1.

VI. ENABLING ASSUMPTIONS:

Same as A4.2.1.1.2-M1.

VII. REQUIRED ANALYSES:

Same as A4.2.1.1.2-M1.

VIII. REQUIREMENTS SATISFIED:
A. Estimated System Performance:
B. Performance Requirements: 


\section{ARCHITECTURE ID NUMBER: A4.2.1.3.1-M1}

II. ARCHITECTURE TITLE: SST Leakage (Retrieval) Mitigation System

III. ARCHITECTURE DEFINITION:

The SST tank farm near-field and vadose zone soil will be utilized as a natural barrier to inhibit the migration of any tank leakage plumes to the environment. This basically represents a no action scenario. Subsurface barriers and other options for mitigating SST leakage that may result from retrieval operations will be evaluated per TPA Milestone M-45-07, (September 1994) "Complete Evaluation of Sub-surface Barrier Feasibility".

\section{ALTERNATIVES CONSIDERED:}

A number of alternative architectures were considered for application to this function:

- $\quad$ No action involves use of the near-field and vadose zone soil as a natural barrier between the tank-farms and the environment. This is the current architecture unless the evaluations and decision process per TPA Milestone M-45-07 lead to selection of another.

- Close-coupled subsurface barriers were considered as an alternative for "Prevention and Minimization of New Leakage"; see A4.2.1.3.1-M1.1.

- Stand-off subsurface barriers were considered as an alternate for "Confinement of Past Leaks"; see A4.2.1.3.1-M1.2.

- Soil Flushing and Excavation were considered as alternates for "Removal of Soil Contamination"; see A4.2.1.3.1-M1.3.

- Subsurface leak detection was considered as an alternate for "Monitor Performance and Verify Integrity"; see A4.2.1.3.1-M1.4.

\section{RATIONALE FOR SELECTION:}

The current TWRS program baseline does not currently include any action to mitigate the threat of leakage from SSTs during retrieval activities. However, the potential for large leaks during retrieval exists. Subsurface barriers are under evaluation as alternative approaches to mitigate the leakage threat.

Historically, tank wastes have been released to the ground as a result of leaks from SSTs and associated transfer lines, and other miscellaneous spills. Sixty-seven SSTs are assumed to have leaked a total volume of approximately 2,271 to $3,407 \mathrm{~m}^{3}$ $(600,000$ to $900,000 \mathrm{gal})$ (Hanlon 1993). In addition to the 67 assumed leaking tanks, 
at least $378 \mathrm{~m}^{3}(100,000 \mathrm{gal})$ of liquid wastes are estimated to have been released to the ground as a result of unplanned releases and spills. The information available for these releases and spills indicates generally low levels of radioactivity. However, several studies (Lowe 1992, Schmittroth 1993) have indicated that the contaminants present in this volume of leakage could cause violation of groundwater quality standards, once the contaminants migrate down through the vadose zone and reach the groundwater.

The Hanford SST tank farms were constructed during the period from 1943 to 1964 . Retrieval of waste from the SSTs is currently scheduled for a 15-year campaign beginning 2003 and ending 2018, except tank C-106, which is planned for retrieval in 1997 to provide a demonstration of retrieval technology. Accordingly, the SSTs will be as old as 60 to 75 years at the initiation of retrieval depending on the sequence for individual tanks.

The primary approach currently envisioned for retrieval of the SST waste is hydraulic sluicing. The sluicing operations will typically add some level of working liquid to the tank to mobilize the solidified salt cakes and sludges. The design life of the tanks has expired and the integrity of the tank containment boundaries is in question. Concerns exist regarding additional leakage that may result due to the hydraulic head and fluid dynamic forces impacting the tank shells during retrieval. The robotic arm-based confined sluicing method for retrieval would likely reduce the chances of leakage; however, leakage during retrieval may still occur in areas where the tank containment structure has deteriorated significantly.

Initial screening studies have identified that use of a close-coupled subsurface barrier designed to prevent new leakage during retrieval may be an appropriate method to mitigate the leakage threat. The other alternatives were eliminated because they would involve responding to leakage that has already occurred. In this situation, a more effective overall strategy for confinement and removal (if needed) would be to take action on contamination from past leaks following completion of retrieval activities on a tank farm by tank farm basis. This would eliminate the need for repetitive removal operations in the event new leakage occurred during retrieval; see Section 2.2, Function/4.2.3.5.2-M1.

\section{ENABLING ASSUMPTIONS:}

Decomposition of architecture 4.2.1.3 will include the fifth-level architecture "Retrieve SST waste."

\section{REQUIRED ANALYSES:}

Evaluation as per TPA Milestone M-45-07A:

"M-45-07A (September 1994) Complete Evaluation of Sub-surface Barrier Feasibility 
Complete a feasibility study of barriers to accomplish the following:

1) Estimate the potential environmental impact of waste storage and retrieval activities without the application of barriers.

2) Establish functional requirements of barriers to minimize the impact associated with the waste storage and retrieval activities.

3) Evaluate the application of existing sub-surface barrier technologies to meet functional requirements of barriers and the potential reduction in environmental impacts from the application of barriers to SST waste storage and retrieval activities."

\section{REQUIREMENTS SATISFIED:}
A. Estimated System Performance:
B. Performance Requirements: 


\section{ARCHITECTURE ID NUMBER: A4.2.1.3.1-M1.1}

II. ARCHITECTURE TITLE: SST Leakage Prevention

III. ARCHITECTURE DEFINITION:

No action will be taken to prevent SST leakage during waste retrieval activities. Per TPA Milestone M-45-07A, subsurface barriers will be evaluated.

IV. ALTERNATIVES CONSIDERED:

- $\quad$ No action involves use of the near-field and vadose zone soil as a natural barrier between the tank-farms and the environment. This is the current architecture unless the evaluations and decision process per TPA Milestone M-45-07 lead to selection of another.

- Close-coupled subsurface barriers involves the installation of barrier material into the soil immediately surrounding the tank structure forming a seal (Figure 2-2). This barrier would prevent new leakage and thereby prevent new soil contamination.

V. RATIONALE FOR SELECTION:

Same as A4.2.1.3.1-M1.

VI. ENABLING ASSUMPTIONS:

Same as A4.2.1.3.1-M1.

VII. REQUIRED ANALYSES:

Same as A4.2.1.3.1-M1.

VIII. REQUIREMENTS SATISFIED:
A. Estimated System Performance:
B. Performance Requirements: 


\section{ARCHITECTURE ID NUMBER: A4.2.1.3.1-M1.2}

\section{ARCHITECTURE TITLE: SST Leakage Confinement System}

\section{ARCHITECTURE DEFINITION:}

No action will be taken to confine soil contamination resulting from previous SST leakage during waste retrieval activities.

\section{ALTERNATIVES CONSIDERED:}

- $\quad$ No action involves use of the near-field and vadose zone soil as a natural barrier between the tank-farms and the environment. This is the current architecture unless the evaluations and decision process per TPA Milestone M-45-07 lead to selection of another.

- $\quad$ Stand-off subsurface barriers involves installation of a layer of barrier material surrounding a tank or tank farm in a geometry that leaves a layer of soil beneath and around the tank structure(s) Figures (2-3 and 2-4). The barrier would be installed and maintained while soil flushing was used to remove contamination - see A4.2.1.3.1-M1.3.

\section{RATIONALE FOR SELECTION:}

Same as A4.2.1.3.1-M1.

VI. ENABLING ASSUMPTIONS:

Same as A4.2.1.3.1-M1.

VII. REQUIRED ANALYSES:

Same as A4.2.1.3.1-M1.

VIII. REQUIREMENTS SATISFIED:
A. Estimated System Performance:
B. Performance Requirements: 


\section{ARCHITECTURE ID NUMBER: A4.2.1.3.1-M1.3 \\ II. ARCHITECTURE TITLE: Soil Contamination Removal System \\ III. ARCHITECTURE DEFINITION:}

No action will be taken to remove soil contamination resulting from SST leakage during retrieval activities.

\section{ALTERNATIVES CONSIDERED:}

- $\quad$ No action involves use of the near-field and vadose zone soil as a natural barrier between the tank-farms and the environment. This is the current architecture unless the evaluations and decision process per TPA Milestone M-45-07 lead to selection of another.

- Soil Flushing involves installation of injection pipes in an upper layer and collection pipes in a lower layer. Flushing liquid is introduced in the injection pipes and leachate is collected at the collection pipes. Soil flushing would be utilized either with or without a subsurface (stand-off) barrier. The barrier would prevent the potential further spread of contamination due to the driving forces of the flushing liquid.

- Excavation involves removing the soil that contains contamination and replacing it with clean soil. The contaminated soil is transferred to a treatment, storage, and disposal facility for treatment.

\section{RATIONALE FOR SELECTION:}

Same as A4.2.1.3.1-M1.

VI. ENABLING ASSUMPTIONS:

Same as A4.2.1.3.1-M1.

VII. REQUIRED ANALYSES:

Same as A4.2.1.3.1-M1.

VIII. REQUIREMENTS SATISFIED:
A. Estimated System Performance:
B. Performance Requirements: 


\section{ARCHITECTURE ID NUMBER: A4.2.1.3.1-M1.4}

II. ARCHITECTURE TITLE: Performance Monitoring and Compliance Verification System

\section{ARCHITECTURE DEFINITION:}

No action will be taken to monitor performance and verify compliance of leakage mitigation systems during retrieval activities, because no physical systems will be installed.

\section{ALTERNATIVES CONSIDERED:}

- $\quad$ No action involves use of the near-field and vadose zone soil as a natural barrier between the tank-farms and the environment. This is the current architecture unless the evaluations and decision process per TPA Milestone M-45-07 lead to selection of another. Because no subsurface barriers are installed in this case, no monitoring or verification of barrier performance is needed.

- Subsurface leak detection involves installation of leak detection instrumentation near or around (belowground) subsurface barrier structures to detect any leakage that may escape the barrier structure. This architecture is needed only if a barrier is used.

\section{RATIONALE FOR SELECTION:}

Same as A4.2.1.3.1-M1.

VI. ENABLING ASSUMPTIONS:

Same as A4.2.1.3.1-M1.

VII. REQUIRED ANALYSES:

Same as A4.2.1.3.1-M1.

VIII. REQUIREMENTS SATISFIED:
A. Estimated System Performance:
B. Performance Requirements: 


\section{ARCHITECTURE ID NUMBER: A4.2.3.5.2-M1} II. ARCHITECTURE TITLE: $\begin{aligned} & \text { SST Leakage Mitigation to Achieve Closure } \\ & \text { Readiness System }\end{aligned}$

\section{ARCHITECTURE DEFINITION:}

No actions are currently planned to mitigate SST leakage prior to transfer of the tanks to the Environmental Restoration Contractor for closure. Subsurface barriers and other options for mitigating SST leakage will be evaluated per TPA Milestone M-45-07, (September 1994) "Complete Evaluation of Sub-surface Barrier Feasibility".

\section{ALTERNATIVES CONSIDERED:}

A number of alternative architectures were considered for application to this function:

- $\quad$ No action involves use of the near-field and vadose zone soil as a natural barrier between the tankfarms and the environment. This is the current architecture unless the evaluations and decision process per TPA Milestone M-45-07 lead to selection of another.

- $\quad$ Stand-off subsurface barriers were considered as an alternate for "Confinement of Past Leaks"; see A4.2.3.5.2-M1.1.

- Soil Flushing and Excavation were considered as alternates for "Removal of Soil Contamination"; see A4.2.3.5.2-M1.2.

- $\quad$ Subsurface leak detection was considered as an alternate for "Monitor Performance and Verify Integrity"; see A4.2.3.5.2-M1.3.

\section{RATIONALE FOR SELECTION:}

The current TWRS program baseline does not currently include any action to mitigate the threat of leakage from SSTs after retrieval and before transfer to the Environmental Restoration Contractor for closure. Subsurface barriers and soil flushing will be evaluated along with other alternatives for potential use in removing soil contamination to the extent practicable in achieving "closure readiness" prior to transfer.

Historically, tank wastes have been released to the ground as a result of leaks from SSTs and associated transfer lines, and other miscellaneous spills. Sixty-seven SSTs are assumed to have leaked a total volume of approximately 2,271 to $3,407 \mathrm{~m}^{3}$ $(600,000$ to $900,000 \mathrm{gal})$ (Hanlon 1993). In addition to the 67 assumed leaking tanks, at least $378 \mathrm{~m}^{3}(100,000 \mathrm{gal})$ of liquid wastes are estimated to have been released to the ground as a result of unplanned releases and spills. The information available for 
these releases and spills indicates generally low levels of radioactivity. However, several studies (Lowe 1992, Schmittroth 1993) have indicated that the contaminants present in this volume of leakage could cause violation of groundwater quality standards, once the contaminants migrate down through the vadose zone and reach the groundwater.

The Hanford SST tank farms were constructed during the period from 1943 to 1964 . Retrieval of waste from the SSTs is currently scheduled for a fifteen year campaign beginning 2003 and ending 2018, except tank C-106, which is planned for retrieval in 1997 to provide a demonstration of retrieval technology. Accordingly, the SSTs will be as old as 60 to seventy-five years at the initiation of retrieval depending on the sequence for individual tanks.

The primary approach currently envisioned for retrieval of the SST waste is hydraulic sluicing. The sluicing operations will typically add some level of working liquid to the tank to mobilize the solidified saltcakes and sludges. The design life of the tanks has expired and the integrity of the tank containment boundaries is in question. Concerns exist regarding additional leakage that may result due to the hydraulic head and fluid dynamic forces impacting the tank shells during retrieval. The robotic arm-based confined sluicing method for retrieval would likely reduce the chances of leakage; however, leakage during retrieval may still occur in areas where the tank containment structure has deteriorated significantly.

The soil contamination resulting from past SST leakage and additional leakage that may occur during retrieval may need to be removed to some extent before the tanks can be declared "closure ready" and transferred to the Environmental Restoration Management Contractor for closure. Requirements for the level of soil clean up have not been determined (DOE/RL-92-60, Rev. 1, Table F4.2, Item 4.2 O3 Issue 1).

Stand-off subsurface barriers with soil flushing and other alternatives will be evaluated to achieve the necessary soil clean-up.

\section{ENABLING ASSUMPTIONS:}

Decomposition of architecture 4.2.3.5 will include the fifth-level architecture "Remove Residual Inventories."

VII. REQUIRED ANALYSES:

Evaluation as per TPA Milestone M-45-07A:

"M-45-07A (September 1994) Complete Evaluation of Sub-surface Barrier Feasibility Complete a feasibility study of barriers to accomplish the following: 
1) Estimate the potential environmental impact of waste storage and retrieval activities without the application of barriers.

2) Establish functional requirements of barriers to minimize the impact associated with the waste storage and retrieval activities.

3) Evaluate the application of existing sub-surface barrier technologies to meet functional requirements of barriers and the potential reduction in environmental impacts from the application of barriers to SST waste storage and retrieval activities."

\section{REQUIREMENTS SATISFIED:}
A. Estimated System Performance:
B. Performance Requirements: 
I. ARCHITECTURE ID NUMBER: A4.2.3.5.2-M1.1

II. ARCHITECTURE TITLE: SST Leakage Confinement System

\section{ARCHITECTURE DEFINITION:}

No action will be taken to confine soil contamination resulting from previous SST leakage for the purpose of preparing the SSTs for closure. Subsurface barriers will be evaluated per TPA Milestone M-45-07A.

\section{ALTERNATIVES CONSIDERED:}

- No action involves use of the near-field and vadose zone soil as a natural barrier between the tank-farms and the environment. This is the current architecture unless the evaluations and decision process per TPA Milestone M-45-07 lead to selection of another.

- Stand-off subsurface barriers involves installation of a layer of barrier material surrounding a tank or tank farm in a geometry that leaves a layer of soil beneath and around the tank structure(s) Figures (2-3 and 2-4). The barrier would be installed and maintained while soil flushing was used to remove contamination - see A4.2.3.5.2-M1.2.

\section{RATIONALE FOR SELECTION:}

Same as A4.2.3.5.2-M1.

VI. ENABLING ASSUMPTIONS:

Same as A4.2.3.5.2-M1.

VII. REQUIRED ANALYSES:

Same as A4.2.3.5.2-M1.

VIII. REQUIREMENTS SATISFIED:
A. Estimated System Performance:
B. Performance Requirements: 


\section{ARCHITECTURE ID NUMBER: A4.2.3.5.2-M1.2}

I. ARCHITECTURE TITLE: Soil Contamination Removal System

\section{ARCHITECTURE DEFINITION:}

No action will be taken to remove soil contamination resulting from previous SST leakage for the purpose of preparing the SSTs for closure. Subsurface barriers will be evaluated per TPA Milestone M-45-07A.

\section{ALTERNATIVES CONSIDERED:}

- $\quad$ No action involves use of the near-field and vadose zone soil as a natural barrier between the tankfarms and the environment. This is the current architecture unless the evaluations and decision process per TPA Milestone M-45-07 lead to selection of another.

- Soil Flushing involves installation of injection pipes in an upper layer and collection pipes in a lower layer. Flushing liquid is introduced in the injection pipes and leachate is collected at the collection pipes. Soil flushing would be utilized either with or without a subsurface (stand-off) barrier. The barrier would prevent the potential further spread of contamination due to the driving forces of the flushing liquid.

- Excavation involves removing the soil that contains contamination and replacing it with clean soil. The contaminated soil is transferred to a treatment, storage, and disposal facility for treatment.

\section{RATIONALE FOR SELECTION:}

Same as A4.2.3.5.2-M1.

VI. ENABLING ASSUMPTIONS:

Same as A4.2.3.5.2-M1.

VII. REQUIRED ANALYSES:

Same as A4.2.3.5.2-M1.

VIII. REQUIREMENTS SATISFIED:
A. Estimated System Performance:
B. Performance Requirements: 
I. ARCHITECTURE ID NUMBER: A4.2.3.5.2-M1.3

II. ARCHITECTURE TITLE: Performance Monitoring and Compliance Verification System

\section{ARCHITECTURE DEFINITION:}

No action will be taken to monitor performance and verify compliance of leakage mitigation systems during SST closure preparation readiness activities, because no physical systems will be installed.

\section{ALTERNATIVES CONSIDERED:}

- No action involves use of the near-field and vadose zone soil as a natural barrier between the tank-farms and the environment. This is the current architecture unless the evaluations and decision process per TPA Milestone M-45-07 lead to selection of another. Because no subsurface barriers are installed in this case, no monitoring or verification of barrier performance is needed.

- Subsurface leak detection involves installation of leak detection instrumentation near or around (belowground) subsurface barrier structures to detect any leakage that may escape the barrier structure. This architecture is needed only if a barrier is used.

\section{RATIONALE FOR SELECTION:}

Same as A4.2.3.5.2-M1.

VI. ENABLING ASSUMPTIONS:

Same as A4.2.3.5.2-M1.

VII. REQUIRED ANALYSES:

Same as A4.2.3.5.2-M1.

VIII. REQUIREMENTS SATISFIED:
A. Estimated System Performance:
B. Performance Requirements: 
WHC-SD-WM-FRD-019 REV. 0

This page intentionally left blank. 


\subsection{INTERFACES}

[Reserved - to be provided later. This section was reserved at this time based on the following reasons: (1) the TWRS fifth-level functions and requirements are not yet formally defined; changes to them would affect interfaces with the functions described herein, (2) the baseline and alternate approaches described herein are under evaluation and may change also affecting interfaces, and (3) the resolution key issues will have an affect on performance requirements and interfaces. Accordingly, it was considered impractical and inefficient to attempt interface definition and requirements allocation to support this draft document.] 
WHC-SD-WM-FRD-019 REV. 0

This page intentionally left blank. 


\subsection{ITEMS NEEDING FURTHER RESOLUTION}

The functional decomposition and analysis reflected in this document required a number of assumptions to be made; also, a number of issues were identified. The issues, assumptions, and required analyses are described in this section.

Section 5.0 of DOE/RL-92-60 Rev. 1, specifically, Tables 5-1, 5-2, and 5-3 identify the issues, assumptions, and required analyses for the TWRS functions and requirements through the fourth level of decomposition. Many of the items identified are applicable, directly or indirectly, to the functions and requirements presented herein. Items that were identified specific to the functions and requirements for leakage mitigation are provided in the following table.

\begin{tabular}{|c|l|}
\hline $\begin{array}{c}\text { Requirement or } \\
\text { Architecture }\end{array}$ & \multicolumn{1}{c|}{ Issue or Enabling Assumption/Required Analyses } \\
\hline 4.2.1.3.1-M1 PA1 & $\begin{array}{l}\text { 4.2.1.3.1-M1 PA1 Issue 1 } \\
\text { The applicability and effectiveness of close-coupled subsurface barriers as an alternative } \\
\text { will be greatly dependant on the general closure philosophy applied to the tank farms } \\
\text { (i.e., landfill closure, vs. clean closure). }\end{array}$ \\
& $\begin{array}{l}\text { 4.2.1.3.1-M1 PA1 Issue 1 Required Analysis } \\
\text { The designation of the 200 Area as a limited use area has not been accepted by all } \\
\text { stakeholder groups and may be subject to challenge. } \\
\text { In conjunction with the Hanford Site Systems Engineering Functions and Requirements } \\
\text { analysis, develop interface requirements for these items. A preliminary closure } \\
\text { strategy and preliminary performance assessment for SSTs/DSTs may be required to } \\
\text { establish interface requirements for the residual waste remaining in the tanks. }\end{array}$ \\
\hline 4.2.3.5.2-M1 PA1 & $\begin{array}{l}\text { 4.2.3.5.2-M1 PA1 Issue 1 } \\
\text { Requirements for mitigation of SST leakage in order to meet the objective of } \\
\text { "closure-ready SSTs" have not been defined (DOE/RL-92-60, Rev. 1, Table F4.2, Item } \\
\text { 4.2 O3 Issue 1). } \\
\text { 4.2.3.5.2-M1 P1 Issue 1 Required Analysis } \\
\text { In conjunction with the Hanford Site Systems Engineering Functions and Requirements } \\
\text { analysis, develop interface requirements for these items. A preliminary closure } \\
\text { strategy and preliminary performance assessment for SSTs/DSTs may be required to } \\
\text { establish interface requirements for the residual waste remaining in the tanks. }\end{array}$ \\
\hline
\end{tabular}


WHC-SD-WM-FRD-019 REV. 0

\begin{tabular}{|c|c|}
\hline $\begin{array}{l}\text { Requirement or } \\
\text { Architecture }\end{array}$ & Issue or Enabling Assumption/Required Analyses \\
\hline $\begin{array}{l}\text { A4.2.1.1.2-M1 } \\
\text { A4.2.1.3.1-M1 } \\
\text { A4.2.3.5.2-M1 }\end{array}$ & $\begin{array}{l}\text { Enabling Assumptions } \\
\text { A4.2.1.1.2-M1. Decomposition of architecture 4.2.1.1 will include the fifth-level } \\
\text { architecture "Store SST waste." } \\
\text { A4.2.1.3.1-M1Decomposition of architecture 4.2.1.3 will include the fifth-level } \\
\text { architecture "Retrieve SST waste." } \\
\text { A4.2.3.5.2-M1Decomposition of architecture 4.2.3.5 will include the fifth-level } \\
\text { architecture "Remove Residual Inventories." } \\
\text { Required Analysis (all architectures) } \\
\text { Evaluation as per TPA Milestone M-45-07A: } \\
\text { "M-45-07A (September 1994) Complete Evaluation of Sub-surface Barrier Feasibility } \\
\text { Complete a feasibility study of barriers to accomplish the following: } \\
\text { 1) Estimate the potential environmental impact of waste storage and retrieval } \\
\text { activities without the application of barriers. } \\
\text { Establish functional requirements of barriers to minimize the impact associated } \\
\text { with the waste storage and retrieval activities. } \\
\text { Evaluate the application of existing sub-surface barrier technologies to meet } \\
\text { functional requirements of barriers and the potential reduction in } \\
\text { environmental impacts from the application of barriers to SST waste storage } \\
\text { and retrieval activities." }\end{array}$ \\
\hline
\end{tabular}




\subsection{REFERENCES}

40 CFR 61, "National Emissions Standards for Hazardous Air Pollutants," Code of Federal Regulations, as amended.

40 CFR 141, "National Primary Drinking Water Regulations," Code of Federal Regulations, as amended.

40 CFR 265, "Interim Status Standards for Owners and Operators of Hazardous Waste Treatment, Storage, and Disposal Facilities," Code of Federal Regulations, as amended.

Anderson, G., 1993, "Tank Waste Barriers, M-06-00" (letter 9303063 to J. D. Bauer, U.S. Department of Energy - Richland Field Office, March 29, 1993), Washington State Department of Ecology, Olympia, Washington.

Anttonen, J. H., 1992, "TWRS National Technology Workshop, June 29, 30 and July 1, 1992" (letter 92-TRB-123 to addressees, August 17, 1992), U.S. Department of Energy - Richland Field Office, Richland, Washington.

ASME NQA-1, Quality Assurance Program Requirements for Nuclear Facilities, American Society of Mechanical Engineers, New York, New York.

Clean Air Act of 1977, as amended, 42 USC 7401, et seq.

Defense Authorization Act, Public Law 101-510, "Safety Measures for Waste Tanks at Hanford Nuclear Reservation," Section 3137 (also known as the Wyden Amendments).

Delaney, C. D., K. A. Lindsey, and S. P. Reidel, 1991, Geology and Hydrology of the Hanford Site: A Standardized Text for Use in Westinghouse Hanford Company Documents and Reports, WHC-SD-ER-TI-003, Westinghouse Hanford Company, Richland, Washington.

DOE, RL, WHC, and PNL, 1993, "Tank Waste Remediation System Leadership Council Meeting, February 4-5, 1993," U.S. Department of Energy, U.S. Department of Energy - Richland Field Office, Westinghouse Hanford Company, Battelle Pacific Northwest Laboratories, Washington, D.C.

DOE Order 5400.5, Radiation Protection of the Public and the Environment, U.S. Department of Energy, Washington, D.C.

DOE Order 5480.19, Conduct of Operations Requirements for DOE Facilities, U.S. Department of Energy, Washington, D.C. 
DOE Order 5820.2A, Radioactive Waste Management, U.S. Department of Energy, Washington, D.C.

DOE/EV/1830-T5, "A Guide to Reducing Radiation Exposure to As Low As Reasonably Achievable (ALARA)," April 1980, U.S. Department of Energy, Washington, D.C.

Ecology, EPA, and DOE, 1990, Hanford Federal Facility Agreement and Consent Order, Washington State Department of Ecology, U.S. Environmental Protection Agency, and the U.S. Department of Energy, Olympia, Washington.

Gibson, S., 1993, "FY 1994 Call for TTPs for the Underground Storage Tank Integrated Demonstration" (memorandum to addressees, February 1, 1993), U.S. Department of Energy, Washington, D.C.

Harrington, R. A., 1993, "Subsurface Barrier Workshop, Study Analysis Session Report (letter 9305205 to S. S. Lowe, Westinghouse Hanford Company, June 21, 1993), Kaiser Engineers Hanford Company, Richland, Washington.

Klem, M. J., 1990, Inventory of Chemicals Used at Hanford Production Plants and Support Operations (1944-1980), WHC-EP-0172, Revision 1, Westinghouse Hanford Company, Richland, Washington.

Lindsey, K. A., B. N. Bjornstad, J. W. Lindberg, and K. M. Hoffman, 1992a, Geologic Setting of the 200 East Area: An Update, WHC-SD-EN-TI-012, Revision 0, Westinghouse Hanford Company, Richland, Washington.

Lindsey, K. A., M. P. Connelly, and B. N. Bjornstad, 1992b, Geologic Setting of the 200 West Area: An Update, WHC-SD-EN-TI-008, Revision 0, Westinghouse Hanford Company, Richland, Washington.

Lowe, S. S. et al., 1993, Engineering Study of Tank Leaks Related to Hydraulic Retrieval of Sludge from Tank 24I-C-106, WHC-SD-WM-ES-218, Revision 1, Westinghouse Hanford Company, Richland, Washington.

National Environmental Policy Act of 1969, as amended, 42 USC 4321, et seq. Reidel, S. P., K. A. Lindsey, and K. R. Fecht, 1992, Field Trip Guide to the Hanford Site, WHC-MR-0391, Revision 0, Westinghouse Hanford Company, Richland, Washington.

Resource Conservation and Recovery Act of 1976, as amended, 42 USC 9601, et seq.

RL, 1993a, Tank Waste Remediation System Functions and Requirements, DOE/RL-92-60, Draft, U.S. Department of Energy - Richland Field Office, Richland, Washington. 
RL, 1993b, Hanford Mission Plan, Volume 1 - Site Guidance, DOE/RL-93-08, U.S. Department of Energy - Richland Field Office, Richland, Washington.

RL Order 6430.1C, Hanford Plant Standards (HPS) Program, U.S. Department of Energy Richland Field Office, Richland, Washington.

Sabin, J. C., 1993, Review of Prior Single-Shell Tank Waste Retrieval Process Studies, WHC-SD-WM-ES-252, Revision 0, Westinghouse Hanford Company, Richland, Washington.

Squires, K. G. et al., 1991, Engineering Study for Partial Retrieval of Tank 241-C-106, WHC-SD-W139-ES-002, Revision 0, Westinghouse Hanford Company, Richland, Washington.

State Environmental Policy Act of 1971, Revised Code of Washington, RCW 43.21C, Olympia, Washington.

WAC 173-160, "Minimum Standards for Construction and Maintenance of Wells," Washington Administrative Code, as amended.

WAC 173-303, "Dangerous Waste Regulations," Washington Administrative Code, as amended.

WAC 173-460, "Controls for New Sources of Toxic Air Pollutants," Washington Administrative Code, as amended.

WAC 246-247, "Radiation Protection - Air Emissions," Washington Administrative Code, as amended.

Wagoner, J. D., 1992, "National Environmental Policy Act (NEPA) Categorical Exclusion (CX) Determination: Site Characterization and Environmental Monitoring, Hanford Site, Richland, Washington" (memorandum 9208799 to C. M. Borgstrom, U.S. Department of Energy, December 4, 1992), U.S. Department of Energy - Richland Field Office, Richland, Washington.

Washington Clean Air Act, Revised Code of Washington, RCW 70.94, Olympia, Washington.

WHC, 1991, Hanford Site Solid Waste Acceptance Criteria, WHC-EP-0063-3, Westinghouse Hanford Company, Richland, Washington.

WHC, 1992, Operating Specifications for Single-Shell Waste Storage Tanks, OSD-T-151-00013, Revision D-1, Westinghouse Hanford Company, Richland, Washington. 
WHC, 1993a, Tank Farm Surveillance and Waste Status Summary Report for May 1993, WHC-EP-182-62, Westinghouse Hanford Company, Richland, Washington.

WHC, 1993b, Integrated Retrieval Program Plan, WHC-SD-WM-PLN-067, Revision 0, Westinghouse Hanford Company, Richland, Washington.

WHC-CM-1-3, Management Requirements and Procedures, Westinghouse Hanford Company, Richland, Washington.

WHC-CM-1-6, WHC Radiological Control Manual, Westinghouse Hanford Company, Richland, Washington.

WHC-CM-4-2, Quality Assurance Manual, Westinghouse Hanford Company, Richland, Washington.

WHC-CM-4-9, Radiological Design, Westinghouse Hanford Company, Richland, Washington.

WHC-CM-4-11, ALARA Program Manual, Westinghouse Hanford Company, Richland, Washington.

WHC-CM-4-40, Industrial Hygiene Manual, Westinghouse Hanford Company, Richland, Washington.

WHC-CM-7-5, Environmental Compliance, Westinghouse Hanford Company, Richland, Washington. 


\section{APPENDIX A}

\section{TWRS SYSTEMS ENGINEERING APPROACH}

A-1 
WHC-SD-WM-FRD-019 REV. 0

This page intentionally left blank. 
APPENDIX A

\subsection{SYSTEMS ENGINEERING APPROACH}

\section{Overview}

In November, 1992 the TWRS Program Leadership Council directed that systems engineering be adopted as the paradigm for development and management of the TWRS program.

As defined in DOE Order 4700.1 , the systems engineering process is a sequence of activities that transforms an identified mission need into a description of system performance parameters and a preferred system configuration. A sound requirements baseline must be established to provide the foundation upon which the systems engineering process can be carried out. Functional analysis, which is just one step within the implementation of the overall systems engineering process, establishes this foundation.

\section{Functional Analysis}

Functional analysis is based on the premise that, when describing a system, it is better to think in terms of the functions that must be performed than a collection of parts that comprise the system. A comprehensive functional analysis begins with a statement of the mission, from which all essential functions that the system must perform are derived. The functional analysis process is sequential and iterative. There are three distinct steps, each leading to three important pieces of information; functions, requirements, and architecture. Iterations to this sequential process lead to progressively increasing levels of detail.

Functions are statements of purpose, defining what the system must do; requirements indicate how well the function must be accomplished; and architecture represents a strategy, a process, or a piece of the actual physical system that satisfies a corresponding requirement. This triad of functions $(F)$, requirements $(R)$, and architectures (A) is needed to completely describe and understand the physical system at each level and to establish a basis for the next level of decomposition.

Figure A-1 illustrates the sequential F-R-A approach that was implemented in a series of workshops by a team of technical experts representing each of the TWRS programs. The technical experts decomposed the top level Remediate Tank Waste function, which is basically the TWRS mission statement, into a set of functions that are both necessary and sufficient to satisfy the parent.

Next, requirements were identified that specify how well each of the functions must be accomplished. Forty documents were selected to be reviewed for the initial set of requirements according to the following criteria: 
Figure A-1.

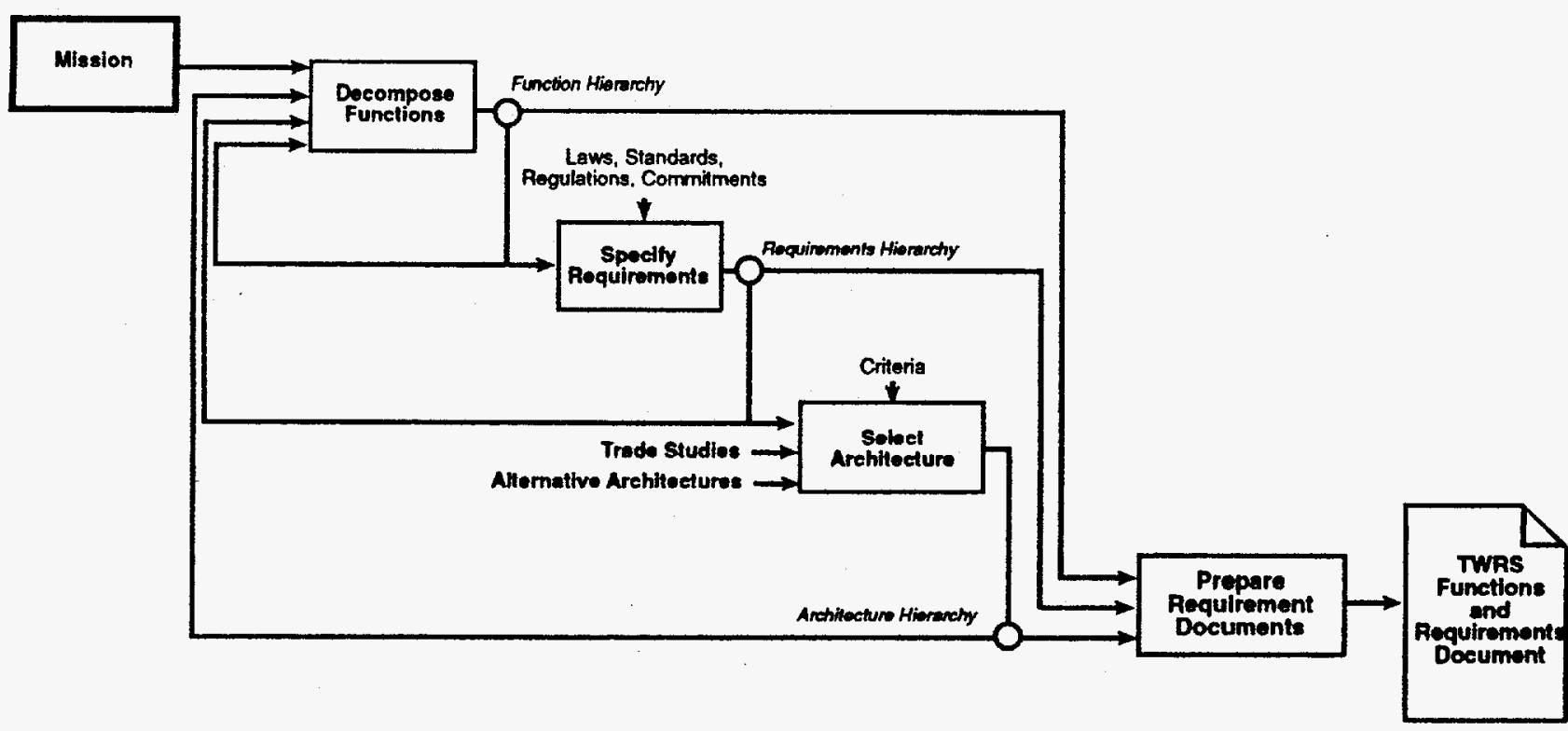

39406123.2 
1. Documents promulgated specifically for work at Hanford

2. Documents promulgated specifically for storing, treating, or disposing of radioactive and/or hazardous waste

3. Documents imposed on TWRS by interfacing DOE facilities

Finally, an architectural concept, not a design, that could satisfy the complete set of requirements was selected. This firmly established the basis for further functional decomposition.

In DOE/RL-92-60 Rev. 1, Tank Waste Remediation System Functions and Requirements, the F-R-A approach was applied through the fourth level of TWRS functional decomposition. Four levels of decomposition were deemed to be sufficient to establish the initial TWRS technical baseline -- the functional requirements baseline -- and to establish the foundation for preparing each of the three Technical Requirement Specifications. Although additional source documents will continue to be reviewed for applicable requirements and alternatives to selected architectural solutions will continue to be evaluated, the information contained in this document is sufficient to specify an initial functional requirements baseline. Follow-on efforts will extend the process to a level of detail that is sufficient to define the missions of individual TWRS projects.

\section{FUNCTION HIERARCHY}

The TWRS function hierarchy to the fourth level of decomposition is shown in Figure A-2. The numbering scheme that uniquely identifies TWRS function titles is based on assigning 4.2 to the Remediate Tank Waste function consistent with the Hanford Sitewide function hierarchy. The third level becomes 4.2.i and the fourth, 4.2.i.j. This scheme, which permits traceability between TWRS functions, their parents and children is used throughout the functional analysis.

\section{FUNCTION DESCRIPTIONS AND REQUIREMENTS}

Requirements allocated to functions or interfaces can be one of two types: constraints, which are requirements imposed on the function/interface by sources external to the TWRS Program (e.g., Congress, Ecology, DOE Orders); or performance requirements, which are imposed on the function/interface by the TWRS Program itself. The numbering convention used for the identification of requirements in these tables is as follows:

4.2.1 $\mathrm{P} 1$ is the first performance requirement $(\mathrm{P})$ allocated to function 4.2.1;

4.2.1 Cl is the first constraint (C) allocated to function 4.2.1;

4.2.1 O1 P1 would be first performance requirement allocated to output number $\mathrm{O} 1$ from function 4.2.1; and

4.2.1. $\mathrm{I} 3 \mathrm{C} 1$ is the first constraint allocated to input number $\mathrm{I} 3$ to function 4.2.1. 
Each requirement that has been extracted from a source document has the appropriate reference noted. Table A-1 presents a template of the Function Description Sheets describing each item. 
Figure A-2. TWRS Function Hierarchy.

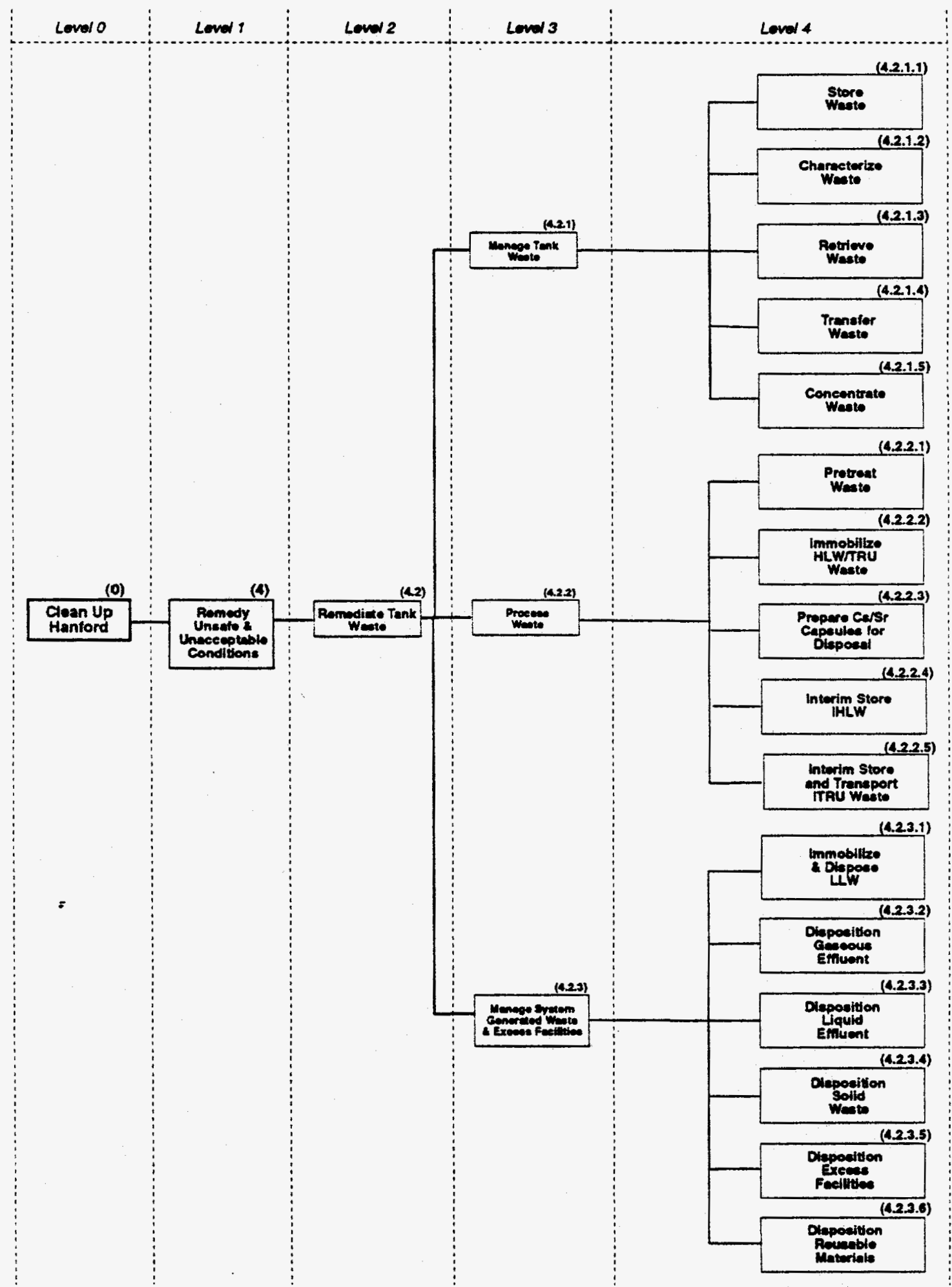

sencti23.3 
Table A-1.

\section{FUNCTION DESCRIPTION SHEETS}

A Function Description Sheet is provided for each of the functions identified. The Function Description Sheets provide the function definitions, enabling assumptions, interfaces, function requirements, and interface requirements. The sheets were prepared according to the format used in DOE/RL-92-60, as shown below.

\section{FUNCTION ID NUMBER:}

I. FUNCTION TITLE: Short description; verb followed by noun or noun phrase.

\section{FUNCTION DEFINITION:}

Primary statement of purpose. Brief description of what this function must accomplish to meet the overall mission, often including the scope of applicability.

\section{ENABLING ASSUMPTIONS:}

Assumed interfaces, end states, and criteria that were made to further define the function, constrain the limits of applicability, or interpret system requirements. These assumptions necessitate additional analyses to determine impacts on the program.

\section{INTERFACES}

\section{A. INPUTS}

Anything that is acted upon by a function to produce desired outputs. Inputs can be classified as either internal or external, depending on whether they originate from within TWRS or from the outside environment, respectively.

\section{B. OUTPUTS}

Anything that leaves the function after it has been acted upon by that function.

\section{FUNCTION REQUIREMENTS}

A qualitative or quantitative statement of how well a function must be performed. Function requirements may be one of two types: Constraints or Performance Requirements.

Constraints:

Requirements imposed upon the function by the external environment (e.g., U.S. Congress, Washington EPA, DOE Orders).

Performance Requirements: 
Requirements imposed upon the function by the TWRS Program itself and, hence, may be traded with respect to other performance requirements to optimize overall performance.

The numbering convention used for the identification of requirements in these tables is as follows:

4.2.1 $\mathrm{C} 1$ is the first constraint (C) allocated to function 4.2.1;

4.2.1 $\mathrm{P} 1$ is the first performance requirement $(\mathrm{P})$ allocated to function 4.2.1;

4.2.1 $\mathrm{I} 3 \mathrm{C} 1$ is the first constraint allocated to input number $\mathrm{I} 3$ to function 4.2.1; and

4.2.1. $\mathrm{O} 1 \mathrm{Pl}$ is the first performance requirement allocated to output number $\mathrm{O} 1$ from function 4.2.1.

\section{INTERFACE REQUIREMENTS}

A requirement that applies to the inputs to, or outputs from, a function. Interface requirements are either constraints or performance requirements. 
Requirements can also be either allocable (e.g., weight) or nonallocable (e.g., ALARA). In general, if a nonallocable requirement is applicable to all functions at a given level in the hierarchy, it is assigned to the common parent function to avoid unnecessary repetition. Specific required analyses have been identified for those allocable requirements that cannot yet be portioned among their lower level, child functions. To capture the full extent of all requirements applicable to a given function, it is necessary to trace back up through the top level function hierarchy. For inputs or outputs that do not change from level to level [e.g., Immobilized High-Level Waste (IHLW)], the requirements allocated to the interface are only listed at the highest level. Subsequent references to the requirements for these outputs contain a statement that the requirements are the same as the higher level input/output.

A number of strategies, processes, or physical systems could be conceived of that would satisfy the prescribed set of constraints and performance requirements. For the most part, firm decisions have not yet been made with regard to which particular alternatives will be selected to satisfy most of these requirements. Nevertheless, the TWRS Program is operating under the assumption that a planning basis does exist, as captured within the Tri-Party Agreement. Process flowsheets representative of this planning basis have been developed and the results (currently these are in the form of mass flow) are expressed in the function description tables as expected system performance.

Because the expected system performance values are the product of ongoing strategic design efforts, they are expected to change over time as the definition of the TWRS matures. As the system definition phase evolves into a more detailed design phase, and more defensible analyses are conducted and the results are reported in documents subject to configuration control, confidence in the expected system performance values will increase. Eventually the expected system performance values will be converted into performance requirements and allocated to the appropriate function and interfaces.

\section{ARCHITECTURE HIERARCHY}

Functional analysis proceeds in a top down fashion. At the higher levels it is not possible to provide a detailed description of the physical systems that will be required to satisfy the corresponding functions subject to their requirements. In general, only architectural concepts can be identified at these levels. Thus, the alternatives, considered for satisfying these high level functions often resemble alternative strategic concepts or alternative processes.

Eventually, a level is reached where the alternatives can be expressed in terms of alternative facilities, equipment, software, etc. At this point the lowest level architectures can then be rolled up to provide a comprehensive description of a higher level architectural concept.

Figure A-3 illustrates the process. 
Figure A-3.

\section{Architectural Decomposition}

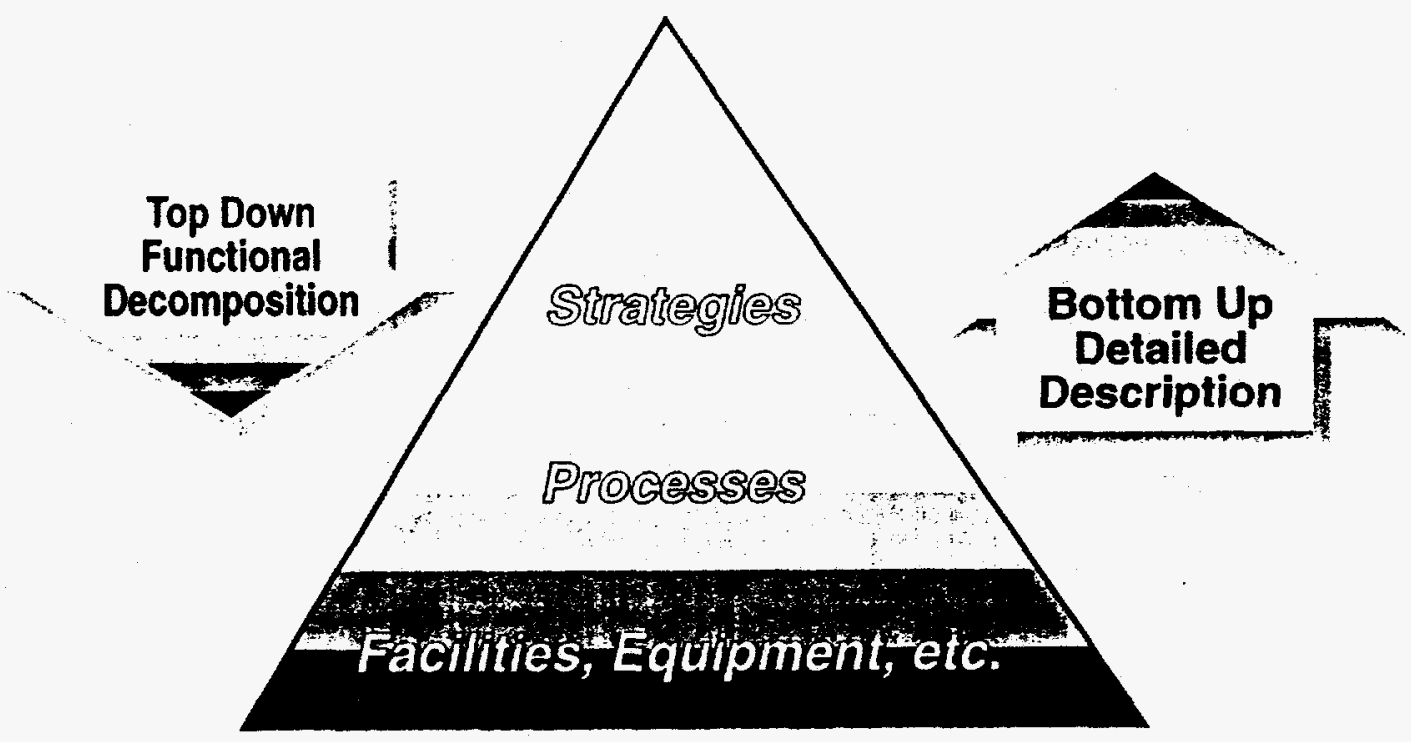

39406123.1 
Any time a selection is made from more than one alternative being considered, there is a corresponding enabling assumption unless there is a defensible basis (e.g., policy decision by DOE, approved document, etc.) for the selection. If there is a defensible basis, this is captured in the Rationale for Selection section of the architecture table and there is no need for an enabling assumption. Even if there is a document that provides a defensible basis for the selection of a specific strategy, process, or facility, all the alternatives considered in the reference document are listed in the architecture table. If an enabling assumption is made, there is at least one required analysis identified. Working from the top (i.e., 4.2) down, the alternatives considered are likely to first be alternative strategic concepts, then alternative process, and finally alternative facilities, equipment, etc.

The complete set of architectural selections comprises the current TWRS planning basis. It is not meant to be a point solution; but it does represent the current TWRS technical baseline. Alternatives will continue to be investigated and, if warranted, controlled changes to the baseline will be implemented.

The TWRS architecture hierarchy to the fourth level of decomposition is shown in Figure A-4. The numbering scheme that uniquely identifies TWRS architecture titles is based on assigning 4.2 to the TWRS consistent with the Hanford sitewide architecture hierarchy. The third level becomes 4.2.i and fourth, 4.2.i.j.

\section{ARCHITECTURE DESCRIPTIONS}

Table A-2 is a template describing the content of the comprehensive architecture description tables that have been prepared. In addition to descriptive information on the architectures, these tables contain a list of the alternatives that were considered, a brief description of the rationale for the chosen architecture, enabling assumptions that were made to allow further progress, the analyses required to resolve the assumptions, and a list of the requirements that have been allocated to the architectures. 


\section{WHC-SD-WM-FRD-019 REV. 0}

Figure A-4.

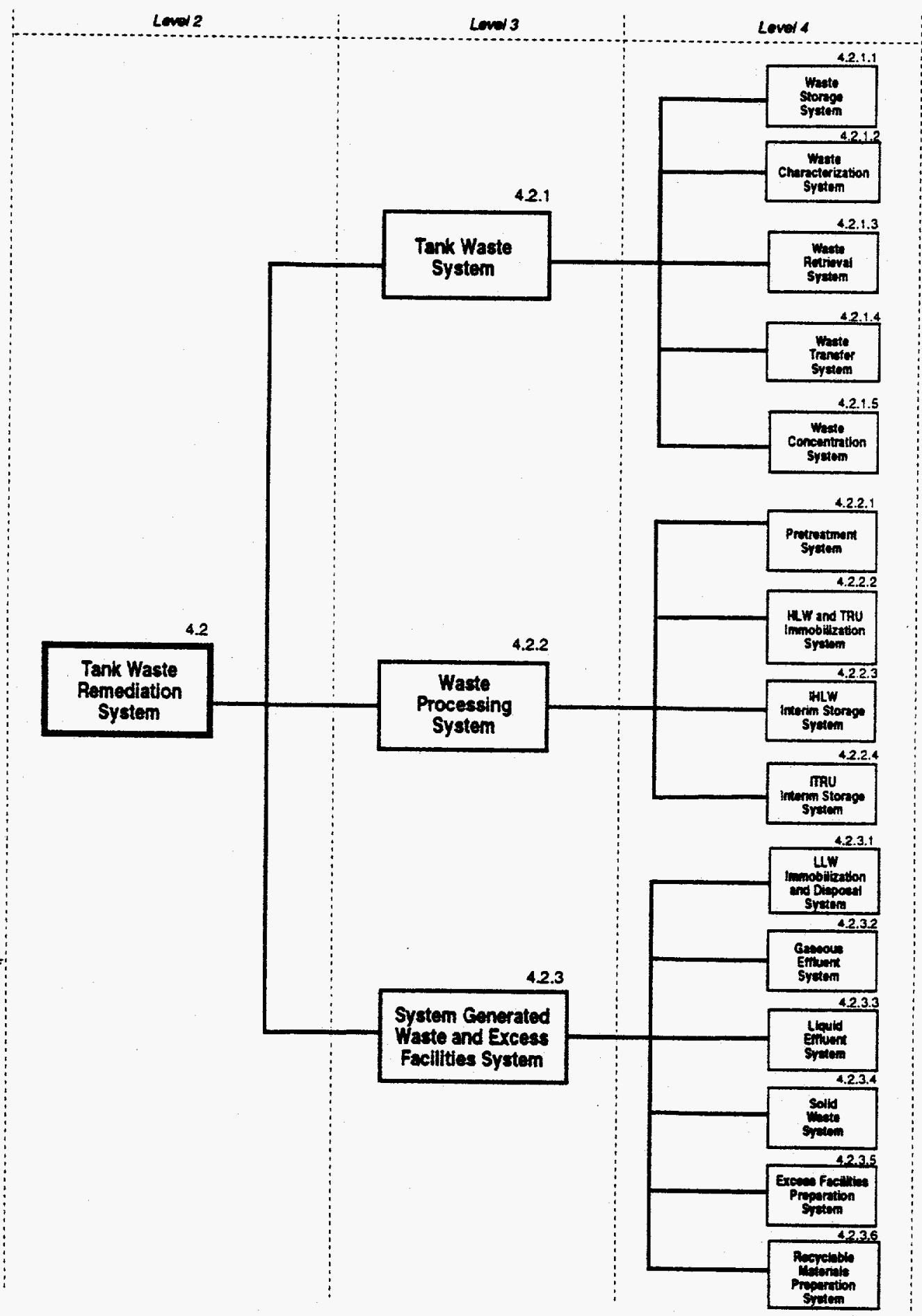

30406123.4 


\section{Table A-2.}

\section{ARCHITECTURE ID NUMBER}

A unique identification number for each architecture of the TWRS architecture tree. As indicated, the numbering scheme is based on using a 4.2 at the top level of the TWRS tree, a 4.2.i at the second level, and a 4.2.i.j at the third level and so forth.

\section{ARCHITECTURE TITLE}

A short description used to identify the architecture.

\section{ARCHITECTURE DEFINITION}

A brief description of the architecture (system, element, or component) that will satisfy some or all of the TWRS requirements.

\section{Alternatives Considered}

A list and short description of the alternative architectures that were considered to satisfy a set of TWRS requirements.

\section{Rationale for Selection}

A short description of the basis for selection a specific architecture.

\section{Enabling Assumptions}

Assumed architectural solutions to enable further functional decomposition. These assumptions necessitate additional analyses to determine impacts on the program.

\section{Required Analyses}

A list of analyses that need to be conducted in order to either further justify the selection of a specific architecture or to resolve outstanding questions and/or issues prior to further functional decomposition.

\section{Requirements Satisfied}

A list of the requirements satisfied by the selected architecture. Each requirement (constraint, performance or expected performance) allocated to a function or interface must be allocated to at least one architectural components. 


\section{APPENDIX B}

GENERAL REQUIREMENTS APPLICABLE TO TANK FARMS 
WHC-SD-WM-FRD-019 REV. 0

This page intentionally left blank. 


\section{APPENDIX B}

\subsection{GENERAL REQUIREMENTS}

In addition to the requirements allocated to specific functions, as identified in the document, the following general requirements shall apply to SST leakage mitigation.

\subsection{DESIGN REQUIREMENTS}

The design of systems, structures, and components shall be in accordance with DOE Order 6430.1A, General Design Criteria, except where formal criteria deviations are approved by the cognizant DOE authority. The requirements of the "-99" Sections and of Division 13 of that order, as applied to nonreactor nuclear faciities and radioactive liquid waste facilities, are applicable.

The design of systems, structures, and components shall comply with the requirements of RL Implementing Procedure (RLIP) 6430.1C, Hanford Plant Standards (HPS) Program, including but not limited to Standard Design Criteria specifically referenced in this document.

Systems, structures, and components important to safety shall be designed to withstand the effects of natural phenomena, including seismic, wind, and missile events. A graded approach to applying natural phenomena criteria shall be employed as described in DOE Order 5480.28, Natural Phenomena Hazards Mitigation, and Hanford Plant Standards, Standard Design Criteria HPS-SDC-4.1, Revision 11, Design Loads for Facilities.

Energy conservation shall be considered in the selection of components using the criteria given in DOE Order $6430.1 \mathrm{~A}$, with the objective to minimize consumption of nonrenewable energy sources and to encourage the use of renewable energy sources.

Systems, facilities, and services shall be designed for year-round operation.

Existing Site utilities shall be used to the maximum extent practicable. 


\subsection{SAFETY REQUIREMENTS}

Structures, systems, and components are categorized into safety classes, as defined in WHCCM-1-3, Management Requirements and Procedures, MRP 5.46, "Safety Classification of Systems, Components and Structures." The safety classes for systems, structures, and components will be determined during a Hazard Analysis and Preliminary Safety Evaluation.

The design of systems, structures, and components shall ensure that a single failure does not result in the loss of capability of a safety class system to accomplish its required safety functions. To protect against single failures, the design shall include appropriate redundancy and shall consider diversity to minimize the possibility of concurrent common-mode failures of redundant items.

Personnel exposure to radiation and hazardous substances shall be mitigated by employing the ALARA process, which incorporates shielding and design configuration. Shielding shall be provided in accordance with the exposure limits of DOE Orders 5400.5, Radiation Protection of the Public and the Environment, and 5480.11, Radiation Protection for Occupational Workers.

Equipment and facilities shall be designed in accordance with the safety requirements of the following:

10 CFR 835, Occupational Radiation Protection

29 CFR 1910, Occupational Safety and Health Standards

RL Order 5480.1A, Environmental, Safety, and Health Program for Department of Energy Operations for Richland Operations

DOE Order 5480.4, Environmental Protection, Safety, and Health Protection Standards

RL Order 5480.4C, Environmental Protection, Safety, and Health Protection Standards for $R L$

DOE Order 5480.7A, Fire Protection

RL Implementing Directive (RLID) 5480.7, Fire Protection

DOE Order 5480.10, Contractor Industrial Hygiene Program

RLIP 5480.10, Industrial Hygiene Program 


\subsection{QUALITY ASSURANCE REQUIREMENTS}

A project-specific Quality Assurance Program Plan (QAPP) shall be developed during Conceptual Design of any project implemented systems and approved/released prior to definitive design. The QAPP implements the quality criteria of DOE Order 5700.6C, Quality Assurance, through the selective and judicious use of ASME NQA-1, Quality Assurance Program Requirements for Nuclear Facilities. The quality program shall provide for a graded approach to the selective application of those active requirements. The basis for establishing that graded approach is the safety classification assigned to systems, structures, and components as described in Section 1.2 above.

Quality Assurance (QA)/Quality Control (QC) activities for all contractors involved in design, construction, inspection, testing and acceptance shall be executed in accordance with the QAPP. The QAPP shall be used by any design contractors to develop verification criteria in design documents, (drawings, specifications, test procedures), and to define QA interfaces for specific requirements and responsibilities on the project.

\subsection{ENVIRONMENTAL REQUIREMENTS}

The project shall comply with the requirements of DOE Order 5400.1, General Environmental Protection Program, as implemented by RLIP 5400.1, General Environmental Protection Program, and with the requirements of WHC-CM-7-5, Environmental Compliance.

\subsection{DECONTAMINATION AND DECOMMISSIONING}

Existing equipment that is being replaced shall be decommissioned as necessary after the new systems are operational. Abandonment of equipment in place is permissible when that option can be shown to be the best economic and technical approach. Equipment and facilities shall be designed to facilitate decontamination and ultimate decommissioning in accordance with DOE Order 6430.1A. 
WHC-SD-WM-FRD-019 REV. 0

This page intentionally left blank. 